\title{
Kimchi and Other Widely Consumed Traditional Fermented Foods of Korea: A Review
}

\author{
Jayanta Kumar Patra ${ }^{1}$, Gitishree Das ${ }^{1}$, Spiros Paramithiotis ${ }^{2}$ and Han-Seung Shin ${ }^{3 *}$ \\ ${ }^{1}$ Research Institute of Biotechnology and Medical Converged Science, Dongguk University-Seoul, Goyang, South Korea, \\ ${ }^{2}$ Department of Food Science and Human Nutrition, Agricultural University of Athens, Athens, Greece, ${ }^{3}$ Department of Food \\ Science and Biotechnology, Dongguk University-Seoul, Goyang, South Korea
}

OPEN ACCESS

Edited by:

Giovanna Suzzi,

University of Teramo, Italy

Reviewed by:

Giuseppe Spano,

University of Foggia, Italy

Amit K. Tyagi,

The University of Texas MD Anderson

Cancer Center, USA

*Correspondence:

Han-Seung Shin

spartan@dongguk.edu

Specialty section:

This article was submitted to

Food Microbiology,

a section of the journal

Frontiers in Microbiology

Received: 04 August 2016 Accepted: 07 September 2016

Published: 28 September 2016

Citation:

Patra JK, Das G, Paramithiotis S and

Shin H-S (2016) Kimchi and Other

Widely Consumed Traditional

Fermented Foods of Korea: A Review.

Front. Microbiol. 7:1493.

doi: 10.3389/fmicb.2016.01493
Different types of fermented foods such as chongkukjang, doenjang, ganjang, gochujang, and kimchi are plentifully available and widely consumed in north eastern Asian countries including Korea. Among them, kimchi is one of the most popular Korean traditional food. It is prepared by fermenting the baechu cabbage together with other vegetables and lactic acid bacteria $(\angle A B)$ with functional potential. Many types of ingredients are added to kimchi to enhance its taste, flavor, nutritional value, texture etc. A number of bacteria are involved in the fermentation of kimchi, but $L A B$ are the dominant species in the fermentation process. The addition of other sub ingredients and formation of different by-products during fermentation eventually leads to eradication of putrefactive and pathogenic bacteria, and also increase the functionalities, nutritional and nutraceutical potential of kimchi. Kimchi possesses anti-inflammatory, antibacterial, antioxidant, anticancer, antiobesity, probiotic properties, cholesterol reduction, and antiaging properties. In the present review an attempt has been made to review the different types of fermented foods found in the Korean peninsula with detailed scientific research regarding preparation, processing, structure of the microecosystem, and health benefits of kimchi.

Keywords: chongkukjang, doenjang, ganjang, gochujang, kimchi, fermentation, lactobacillus

\section{INTRODUCTION}

The unique geographical location of Korea and the isolation from neighboring countries imposed by rugged mountains from the north and rocky ocean from the east, south, and west, largely contributed to the development of a distinct ethnic group with unique culture. Through time, simplicity has become a basic notion of the Korean philosophy. This simplicity is also reflected in the food habits. A fundamental aspect of this culture has been the preservation of fish, meat, pulses, and vegetables from times of abundance to times of scarcity through lactic acid fermentation; a process applied for more than 1500 years (Han et al., 1998; Surh et al., 2008; Oh et al., 2014).

Intake of a specific dose of fruits and vegetables in the daily food to prevent different types of chronic pathologies and diseases such as coronary heart problems, hypertension, and risk of strokes has been recommended by the Food and Agriculture Organization (FAO) and the World Health Organization (WHO) (Swain et al., 2014). Consumers are always concerned about the safety of the types of food they consumed along with their nutritional and beneficial effect to the health (Endrizzi et al., 2009). Keeping this concept in mind, the preservation and storage of various food materials 
in order to increase their nutritional content and protect their shelf-life has been practiced since time immemorial and this process has been most commonly known as fermentation in most scientific terminology. This process has been developed in order to preserve different types of fruits and vegetables by organic acid and alcohols during their harvesting season and use them at the time of scarcity. Fermented foods and beverages, whether of plant or animal origin, play a vital role in the diet of people in many parts of the world including the Asian and the Western countries. Fermented foods not only provide important sources of nutrients but have also great potential in maintaining health and preventing diseases along with the addition of desirable flavor, texture, reduction of toxicity, and decrease in cooking time (Rolle and Satin, 2002; Kabak and Dobson, 2011).

Generally, the fermentation process is the slow breakdown of organic substances that is prompted by a group of microorganisms or enzymes and results in the alteration of carbohydrates to organic acids or alcohols (FAO, 1998). The fermentation products vary considerably due to the use of various raw materials and preparation techniques (Surh et al., 2008). Customarily the lactic acid (LA) fermentation of vegetables and fruits is a common practice for improvement of nutritional and sensory features of food products (Demir et al., 2006; Di Cagno et al., 2013). A number of lactic acid bacteria (LAB) including Lactobacillus brevis, Lb. fermentum, Lb. plantarum, Leuconostoc mesenteroides, Weissella confusa and Pediococcus pentosaceus are regularly retrieved and have been widely used in the fermentation process (Jung et al., 2014). A number of fermented food products including cereal-based fermented food and non-alcoholic beverages, fermented milks, fermented fruits and vegetables and fermented meat products etc. have been consumed in most parts of the world (Kabak and Dobson, 2011). However, there are some differences in the preparation of traditional foods and beverages from region to region. The process of fermentation of fruits and vegetables has been passed down to subsequent generations as a family tradition and techniques and thus there is no strict procedure of fermentation (Swain et al., 2014). However, drying and salting are the most common practices that are applied in the old food preservation procedure. A number of fermented foods available in the Korean cuisine have been studied to some extend (Jang et al., 2011; Dharaneedharan and Heo, 2016; Koo et al., 2016; Tamang et al., 2016). Among them, kimchi, chongkukjang, doenjang, ganjang, and gochujang may be regarded as characteristic ones. Moreover, kimchi has met worldwide recognition and commercial significance. In the present review, all available literature on the afore mentioned Korean fermented foods with particular focus on scientific research regarding preparation, processing, structure of the microecosystem and health benefits of kimchi are integrated and critically reviewed.

\section{FERMENTED FOOD OF KOREA}

There are numerous fermented foods and beverages, which are the essential element of the Korean cuisine and are consumed by the Koreans as well as many people around the world throughout the year. These fermented food products have also become popular in the western countries and are well appreciated by the people around the world. The major fermented food items, except the alcoholic beverages that are consumed nowadays in Korea, are basically divided into three broad categories (Table 1) (Surh et al., 2008).

\section{First Category}

The first category consists of the soy-based products, that includes chongkukjang (quick fermented soybean paste), doenjang (soybean paste), ganjang (soy sauce), and gochujang (hot pepper-soybean paste) (Surh et al., 2008). Traditionally, these types of fermented products are prepared once in a year, stored in large clay pots and consumed throughout the year.

\section{Chongkukjang}

Chongkukjang is a fermented product manufactured by short term fermentation of boiled soybean seeds using Bacillus subtilis in rice straw. It is one of the favorite traditional foods in Korea (Su et al., 2007; Kwon et al., 2011; Shin and Jeong, 2015). It contains a number of useful microorganisms and bioactive compounds that are absent from unfermented soybean products. Chongkukjang has the shortest fermentation period of 2-4 days and is fermented at a high temperature $\left(40-43^{\circ} \mathrm{C}\right)$. The soybean proteins are degraded during fermentation process by the protein degrading enzymes of $B$. subtilis, and flavonoid glycosides are converted into aglycones by hydrolysis during fermentation, resulting in production of free amino acids along with related peptides (Nakajima et al., 2005; Kim N. Y. et al., 2008; Wei et al., 2015). The Koreans have been consuming Chongkukjang for hundreds of years. Significant amount of data suggests that Chongkukjang contains a number of proteins and minerals that can stimulate the generation and growth of human cells and strengthen the immune system (Choi et al., 2014; Shin and Jeong, 2015). Moreover, there are several reports on the bioactive potential of Chongkukjang such as antidiabetic, antiinflammatory, antimicrobial, antioxidant, blood pressure lowering activities, and neuroprotective effects (Kang et al., 1998; Cho et al., 2000; Yang et al., 2003; Kim et al., 2004; Kim N. Y. et al., 2008; Wei et al., 2015). Compounds like isoflavones (daidzein and genistein) are found at high concentrations in Chongkukjang and they were reported to possess the protective effect against oxidative damage related with atherosclerosis and cancer (Barnes et al., 1996; Anthony et al., 1998).

\section{Doenjang}

Doenjang is traditionally used in Korea as a basic seasoning (Kim et al., 2009; Nam et al., 2015). It is produced by the fermentation of cooked and crushed soybean seeds or blocks, $M e j u$, by naturally occurring bacteria and fungi with brine in a container such as a porcelain pot and has been consumed for centuries as a source of protein and flavoring ingredient in Korea (Kim et al., 2009; Kwon et al., 2010). During recent times, the doenjang has been prepared commercially by various local firms around the Korean peninsula using a slightly modified procedure that varies in the quality as affected by the fermentation process, microbiota involved, and by the basic ingredients used, such 
TABLE 1 | Different types of fermented food available in the Korean peninsula and their medicinal values.

\begin{tabular}{|c|c|c|c|c|c|}
\hline Category & Name & Preparation process & Photo & Medicinal value & References \\
\hline \multirow[t]{4}{*}{ First category } & Chongkukjang & $\begin{array}{l}\text { Short term fermentation of } \\
\text { boiled soybean seeds using } \\
\text { Bacillus subtilis and rice straw }\end{array}$ & & $\begin{array}{l}\text { Rich in proteins, vitamins and } \\
\text { minerals. Immunostimulant, } \\
\text { antimicrobial, anti-inflammatory, } \\
\text { antioxidant, neuro-protective etc. }\end{array}$ & $\begin{array}{l}\text { Kang et al., 1998; Cho } \\
\text { et al., 2000; Yang et al., } \\
\text { 2003; Kim et al., } 2004\end{array}$ \\
\hline & Doenjang & $\begin{array}{l}\text { Fermentation of cooked } \\
\text { soybean seeds with natural } \\
\text { occurring bacteria }\end{array}$ & & $\begin{array}{l}\text { Anticancer, antimutagenicity, } \\
\text { antioxidative, and fibrinolytic activity }\end{array}$ & $\begin{array}{l}\text { Lim et al., 1999, 2004; } \\
\text { Ra et al., } 2004\end{array}$ \\
\hline & Ganjang & $\begin{array}{l}\text { Soybean sauce prepared from } \\
\text { fermented soybean }\end{array}$ & & Antioxidant potential & Choi et al., 1990 \\
\hline & Gochujang & $\begin{array}{l}\text { Fermented paste of red chili } \\
\text { powder }\end{array}$ & & Antioxidant & Choi, 2012 \\
\hline Second category & $\begin{array}{l}\text { Fish and } \\
\text { Shellfish } \\
\text { products }\end{array}$ & $\begin{array}{l}\text { Fermented fresh fish and } \\
\text { shellfish }\end{array}$ & & $\begin{array}{l}\text { Essential source of vitamins, } \\
\text { proteins, and minerals }\end{array}$ & Prester, 2011 \\
\hline Third category & Kimchi & $\begin{array}{l}\text { Short fermentation of napa } \\
\text { cabbage together with other } \\
\text { ingredients }\end{array}$ & & $\begin{array}{l}\text { Antioxidant, anti-obesity, anticancer, } \\
\text { antibacterial, cholesterol lowering, } \\
\text { immune potential, source of } \\
\text { functional foods }\end{array}$ & $\begin{array}{l}\text { Kim et al., 1997; Wu } \\
\text { et al., 2000; Yoon et al., } \\
\text { 2004; Han et al., 2011; } \\
\text { Park et al., } 2014\end{array}$ \\
\hline
\end{tabular}

as soybeans or a combination of soybeans and grains (Yoo et al., 2000; Park et al., 2002). Doenjang has attracted much attention due to its health-related beneficial properties such as anticancer, anti-mutagenicity, antioxidative, and fibrinolytic activity (Lim et al., 1999, 2004; Ra et al., 2004). Various types of microorganisms are involved in the fermentation of doenjang; 
the unique flavors and tastes are due to the decomposed products of soybean proteins from the soybean seed by the action of microorganisms during the fermentation process. A number of reports have stated that $B$. subtilis and $B$. licheniformis are the dominant microorganisms in doenjang along with Aspergillus, Mucor, and Rhizopus species (Kang et al., 2000; Nam et al., 2015). During the fermentation process, cleavage of $\beta$-glycosyl bond of isoflavone glucoside increases the content of isoflavone aglycones, including daidzein and genistein due to the rapid microbial growth (Nam et al., 2015). Daily intake of doenjang has been reported to suppress the body weight gain, cytokine levels, and serum oxidative stress in high-fat-fed mice (Nam et al., 2015). Similarly, the anti-inflammatory and anti-oxidative stress effects of doenjang have also been reported in the adipose tissue (Nam et al., 2015).

\section{Ganjang}

Ganjang is a kind of Korean soybean sauce made from fermented soybeans (Hong-beum, 2004). It contains approximately 15$20 \%$ salt, $50-70 \%$ water, free sugars, isoflavones, peptides, and organic acids that are produced from the soybeans during the fermentation process (Jeon et al., 2002; Shim et al., 2008). The sauce has a characteristic black color due to the presence of melanoidins, which are formed when carbonyl compounds and amino compounds combine together (Kim et al., 2011). The melanoidins present in soybean sauce are responsible for its antioxidant potential (Choi et al., 1990). Ganjang is prepared from the soybeans blocks, meju, which is dried for about 1 week and then tied with straw and dried for another 40 days. After the meju have dried, they are then fermented in a specially made clay pot mixed with salt and water. When the fermentation is complete, dark liquid separates, which is called ganjang (soy sauce or soya sauce) (Hong-beum, 2004).

\section{Gochujang}

Gochujang is a fermented paste made of red chili powder, glutinous rice powder, pureed soybeens and salt, seasonings like garlic and onion, sweetened with a little sugar syrup and fermented for long period in specially designed earthen vessels (Choi, 2012). It is an essential part of the Korean cuisine and is used in almost all the Korean foods like bibimbap, noodles etc. It is a basic ingredient for other sauses and pastes, it is mixed with the doenjang to make samjang, it is used to prepare the chogochujang, salad dressing etc. (Choi, 2012).

\section{Second Category}

The second type of fermented food that is popularly consumed in Korea is prepared from fish and shellfish. These products are consumed as such or are combined with kimchi (Surh et al., 2008). Fish, shellfish and their products provide a healthy source of essential vitamins, high quality proteins, minerals, and polyunsaturated fatty acids (Prester, 2011).

\section{Third Category}

The third category is the kimchi, which is most widely and popularly consumed not only in Korean peninsula but around the world. It is a major Korean traditional fermented food. Kimchi is prepared from the Chinese cabbage (Brassica rapa L. spp. pekinensis [Lour.] Han) and/or radish as its main ingredient, along with different kind of vegetables (Surh et al., 2008). The fermentation process is completed within short period of time. A detailed study on the preparation, processing, and microecosystem is discussed subsequently in the present review.

\section{"KIMCHI" KOREAN WELL KNOWN FERMENTED FOOD}

Kimchi is the most important traditional fermented food in Korea and one of the most widely consumed in other East Asian countries like Japan and China. Information about kimchi can be retrieved from the ancient Korean book "Samkuksaki," published in 1145 A.D., as well as in many other documents such as the subsequent "Naehun," "Hunmongjahoe," "Sinjeung-yuhap," and "Kanibuckonbang" (Cheigh and Park, 1994; Jang et al., 2015; Yang H. J. et al., 2015). According to them, kimchi was considered as the outcome of a simple vegetable in brine fermentation prepared in a stone jar (Cheigh and Park, 1994). Since then, several kimchi types have been recorded according to variations in their composition or preparation method (Surh et al., 2008). In that sense, kimchi prepared with the use of leaf mustard, sweet potato, radish or young radish with leaves (Dongchimi, Chonggak, Beeneul), dropwort, various wild grasses, lettuce (Gotchorri), cucumber (Sobagi, Ggagduki), eggplant, pumpkin, burdock, sliced vegetables (Nabak), leek, scallion, garlic, chicken, pheasant, ear shell, green laver as well as seafood are available in local markets of the Korean peninsula (Figure 1).

\section{Kimchi Ingredients and Preparation}

The wide variety of raw materials used for kimchi preparation makes it unique among the products for the production of which lactic acid fermentation is employed. This variety generates an array of products with escalating organoleptic intensity, which makes it suitable for every age and taste.

\section{BASIC INGREDIENTS}

The raw materials are divided into four classes (Cheigh and Park, 1994): (a) major raw materials, (b) spices, (c) seasonings, and $(\mathrm{d})$ other additional materials. Although Chinese cabbage is more often reported as the major ingredient, as many as 30 different types of vegetables, including radish, young Oriental radish, ponytail radish, and cucumber may be used as well (Kim et al., 2012). The spices regularly used include red and black pepper, cinnamon, garlic, ginger, onion, and mustard. The seasonings most frequently used include salt and salt-pickled seafood, corn syrup, sesame seed, and soybean sauce. Finally, mushrooms as well as vegetables such as carrot, leek, and water cress, seafood like oyster and shrimp, cereals like barley and rice, fruits like apple and pear, meats like pork and beef and many more depending upon availability, geographical region and desired taste fall into the last class of ingredients. Qualitative and quantitative variation in the aforementioned ingredients is 


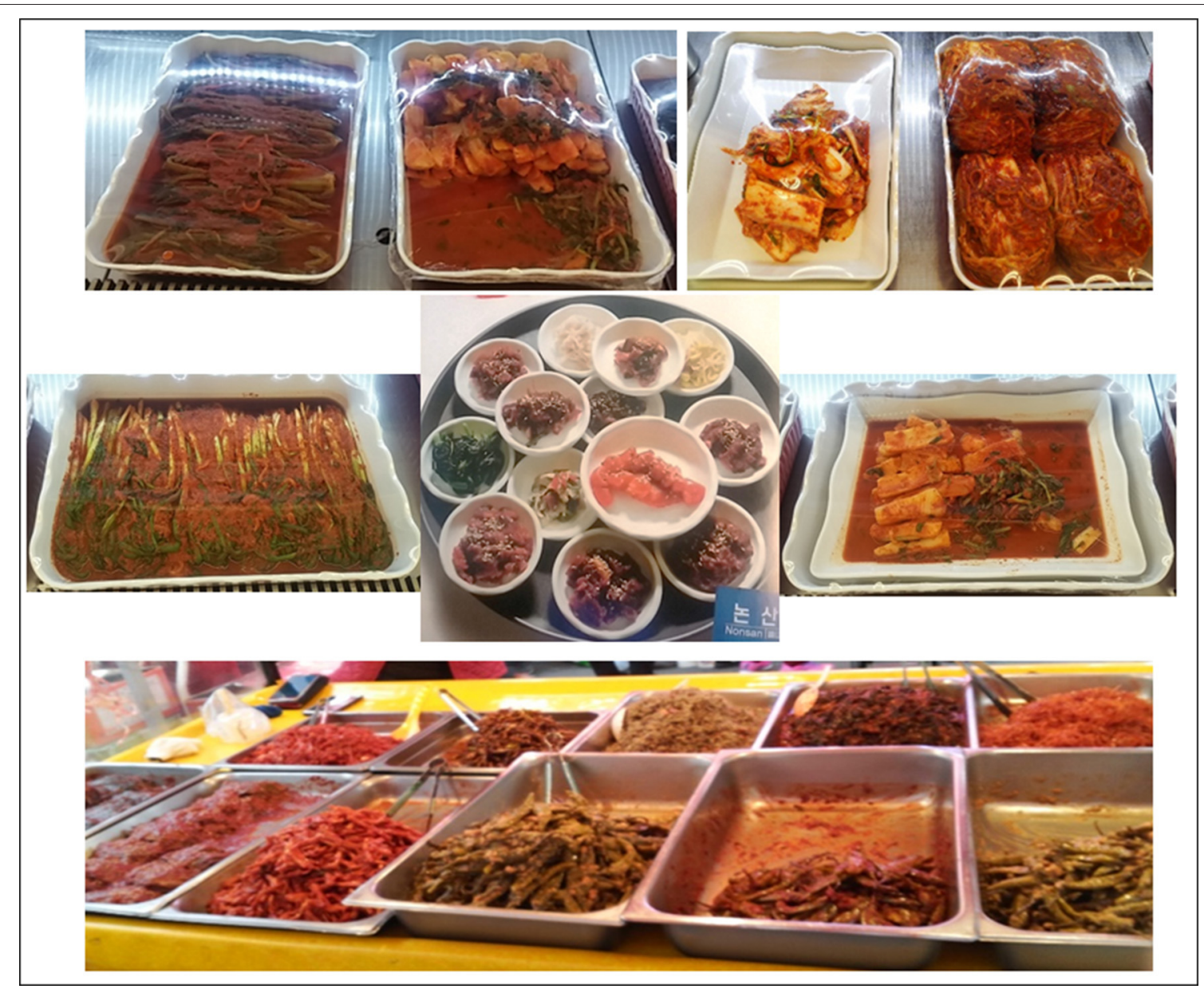

FIGURE 1 | Different types of kimchi available in Korean peninsula.

reflected in the sensorial properties of the final product; in that sense, adjustment of the taste is feasible. The Chinese cabbage kimchi, locally referred to as "Baechu," is the most popular type of kimchi in Korea. For the preparation of this product the average composition of the different raw materials is as follows: Chinese cabbage $74-90 \%$, radish $2.8-13.5 \%$, garlic $1.4-$ $2.0 \%$, ginger $0.5-1.0 \%$, onion $1.5-2.0 \%$, green onion $1.0-3.5 \%$, red pepper $1.8-3.0 \%$, and a wealth of optional ingredients such as leek, shrimp and anchovy paste etc. each added below 2.0\%; the final salt level is calculated at 2.5\% (Park et al., 1994; Cho, 1999; Park and Cheigh, 2003; Lee et al., 2005; Cho et al., 2006).

\section{PREPARATION PROCEDURE}

\section{Homemade Kimchi}

In Figure 2, the basic preparation method is described. Initially, all raw materials are collected. Their selection depends upon taste preferences, availability of raw materials, family tradition, social status etc. Chinese cabbage, the major ingredient, is trimmed to small pieces and thoroughly washed. The excess water is drained and brining takes place. During brining, a small amount of table salt is added and left for $2-3 \mathrm{~h}$. During this time, washing, grading, cutting and mixing of the remaining raw materials takes place. When brining is completed, the excess amount of water is drained again and all the raw materials are mixed (Cheigh and Park, 1994; Park et al., 2014). Fermentation conditions depend upon consumption and storage needs; short-term consumption requires fermentation at room temperature whereas longer storage times requires fermentation at low temperature $\left(5^{\circ} \mathrm{C}\right)$. The product can be called as kimchi only after the completion of the fermentation process (Kim et al., 2012; Oh et al., 2014).

\section{COMMERCIAL PRODUCTION OF KIMCHI}

Kimchi has become one of the most important globally popular food products, because of its taste and health claims; therefore its market has increased worldwide (Jung et al., 2014). The major challenge regarding industrial kimchi production is obtaining uniform quality. This task may be achieved by careful standardization of the whole production procedure, i.e., use of high quality raw materials, starter cultures and suitable fermentation conditions. Due to the large number of 


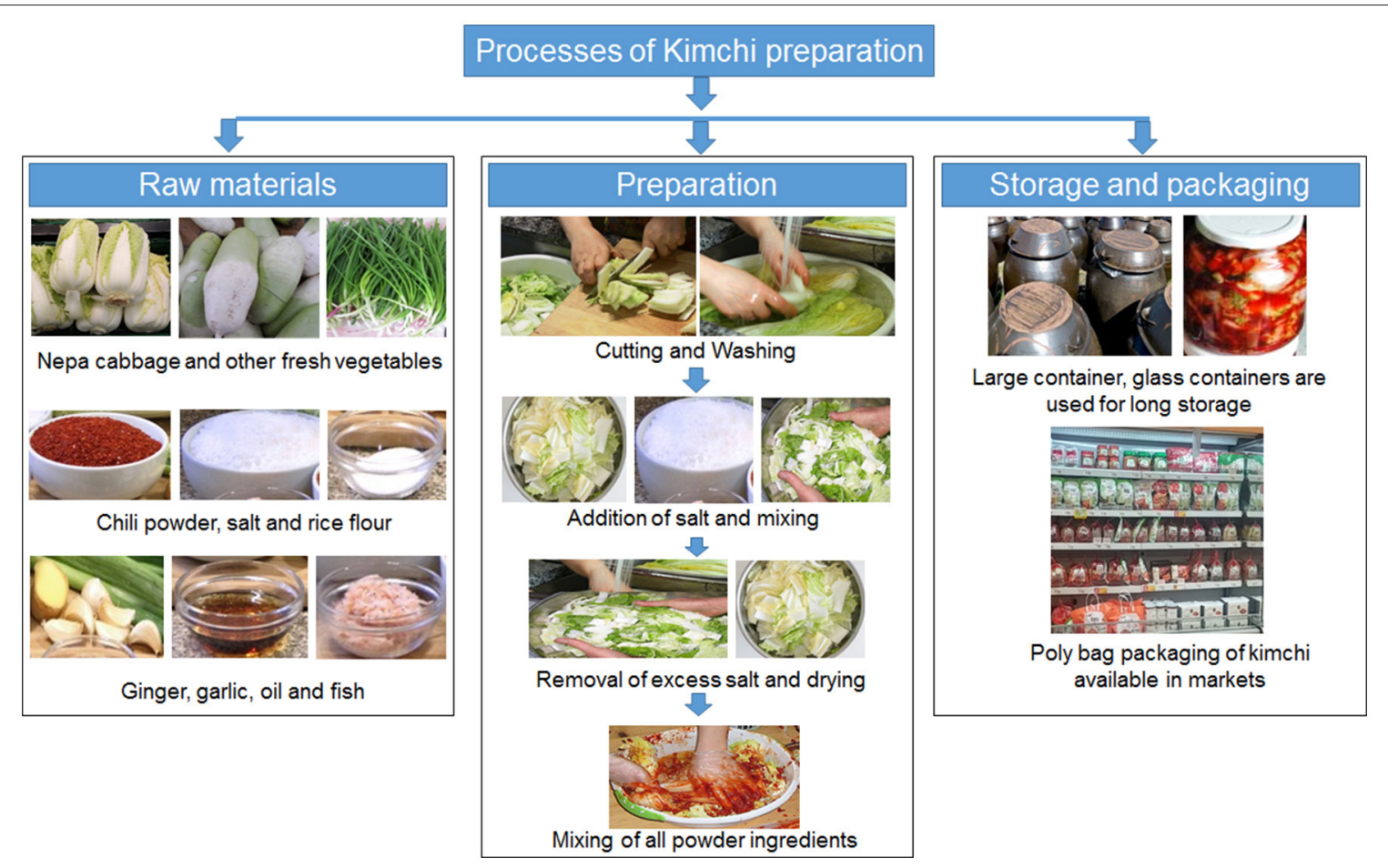

FIGURE 2 | A schematic representation of the traditional process for kimchi preparation.

health claims, a large proportion of which is attributed to the microbiota itself (see paragraph "health benefits"), the criteria for the selection of starter cultures include the evaluation of the medicinal potential. In that sense, LAB such as Ln. mesenteroides, Ln. citreum, and Lb. plantarum have been successfully applied as starter cultures for kimchi preparation (Kim et al., 2012; Ryu et al., 2012). However, the adaptability to the kimchi microenvironment that may be assessed through persistence, as well as technological properties, such as production of organic acids, mannitol, compounds that may affect the product organoleptically, biogenic amines, vitamins, and bacteriocins should also be considered (Lee et al., 2011, 2015; Jung et al., 2014).

\section{STORAGE AND PRESERVATION}

The Korean made kimchi requires less quantity of salt due to the use of red pepper powder (Oh et al., 2014). As a result, kimchi can be stored for long periods of time facilitating commercialization that has increased sharply in countries like Korea, China, Japan, and the United States due to their popularity among the people (Kim et al., 2012). Kimchi is usually stored in two ways, either for 3 weeks at $4^{\circ} \mathrm{C}$, which is considered as well ripened or for only 3-4 d at room temperature. The raw kimchi is eaten in various ways as salad mixed with sesame seeds, sesame seed oil and sugar, while the over-ripened kimchi is usually boiled with meat (jigae). It has been reported that the average consumption of kimchi for the Korean population on daily basis is $124.3 \mathrm{~g}$, with maximum of $154.5 \mathrm{~g}$ consumed in the age group 30-49 years old (Surh et al., 2008). The most important problem in the commercialization of packaged kimchi is the continuous fermentation process by LAB during distribution and storage that eventually decreases significantly the quality of the product. Over-fermentation of kimchi results in excessive acidification (sour taste) due to the production of acid by LAB with softening of its texture and diffusion of color (Cheigh and Park, 1994; Lim et al., 2001). Thus, the extension of kimchi shelf life and maintaining of its quality by minimizing LAB growth, is a major concern for the kimchi industry (Swain et al., 2014).

\section{BIOLOGICAL CHANGES DURING KIMCHI FERMENTATION}

\section{Physicochemical Changes}

Kimchi fermentation may be divided into four stages on the basis of the acidity produced (Codex, 2001): (1) initial stage with acidity $<0.2 \%$, (2) immature stage with acidity between 0.2 and $0.4 \%$, (3) optimum-ripening stage with acidity between 0.4 and $0.9 \%$, and (4) over-ripening or rancid stage with acidity $>0.9 \%$. The dominating $\mathrm{LAB}$ are responsible for the production of the acidity, through fermentation of the available carbohydrates. Type and quality of the raw materials, as well as fermentation conditions decisively affect the course of fermentation. Given the extended variety of the former and the variations observed in the latter, generalizations regarding microbial succession and dominance at species level 
may be at least uncertain, as will be discussed in the next paragraph.

\section{Microbial Community Structure}

The involvement of different types of microorganisms in kimchi fermentation process was studied for the first time in Korea in 1939, and since then many LAB have been isolated and thoroughly characterized (Lee et al., 1997). Apart from this, many other traditional fermented foods were also studied for their microbiota composition (Jang et al., 2011; Dharaneedharan and Heo, 2016; Koo et al., 2016; Tamang et al., 2016). However, in the present study, emphasis was given on the kimchi microbiota because it is the most consumed fermented food in Asia and other continents of the world. Assessment of the kimchi microecosystem was initially performed by culturedependent methods. However, due to the inherent limitations, the number of studies using culture-independent approaches, such as Denaturing Gradient Gel Electrophoresis (DGGE) and pyro-sequencing has been increased over the last decade (Jung et al., 2013; Jeong et al., 2013a; Park et al., 2014). Although application of these techniques has not improved our knowledge regarding the composition of the microecosystem, both qualitatively and quantitatively, an enhancement of speed as well as in some cases reliability has been observed.

In Table 2 the LAB species that participate in the microbial consortium during kimchi fermentation is presented. Several species, such as Ln. carnosum, Ln. mesenteroides, Ln. gelidum, $L n$. lactis, W. confusa, Lb. plantarum, and Lb. sakei seem to be stable elements of the microecosystem whereas species such as Ln. citreum, Ln. gasicomitatum, Ln. kimchi, W. koreensis, $W$. cibaria, Lb. spicheri, Lb. parabrevis, Lb. brevis, and Lb. curvatus may be sporadically present (Kim and Chun, 2005; Lee D. et al., 2008). The factors affecting the course of fermentation as well as the dominating LAB population have been extensively studied. Incubation temperature has been recognized as the most important factor. Lee et al. (2005) applied PCR-DGGE to assess the composition of the LAB microbiota during fermentation at 10 and $20^{\circ} \mathrm{C}$ for 30 and $20 \mathrm{~d}$, respectively. W. confusa, $L n$. citreum, Lb. sakei, and Lb. curvatus formed the LAB consortium that prevailed from the beginning of the fermentation in both temperatures. In the case of $20^{\circ} \mathrm{C}$ this consortium was enriched with Lb. brevis and Lc. lactis subsp lactis. Cho et al. (2006) studied the effect of a preliminary incubation at 10 and $15^{\circ} \mathrm{C}$ for 4 and $2 \mathrm{~d}$, respectively, before the main incubation that took place at $-1^{\circ} \mathrm{C}$ for 90 days, on the composition of the microecosystem. W. koreensis was reported as predominant in both cases. Moreover, when pre-incubation took place at $10^{\circ} \mathrm{C}$, $W$. koreensis dominated the fermentation from the beginning. On the contrary, Ln. citreum and Ln. gasicomitatum prevailed during preliminary incubation at $15^{\circ} \mathrm{C}$. The latter species remained detectable until the end of fermentation. PCR-DGGE was also used by Hong et al. (2013) to compare the bacterial community changes during kimchi fermentation at 4 and $10^{\circ} \mathrm{C}$. In the former case, $W$. confusa, $L b$. sakei, Lb. curvatus, $L n$. gelidum, and Ln. carnosus were reported to dominate the whole fermentation whereas in the latter case a consortium consisting of $W$. confusa and $L b$. curvatus as stable elements throughout fermentation and occasionally by $L n$. citreum, $L b$. parabrevis, Lb. sakei, W. koreensis, and Ln. mesenteroides was reported.

Sodium chloride is a basic ingredient of kimchi preparation. Reduction of sodium chloride generally in fermented products has been extensively studied due to the correlation with elevated blood pressure and increasing occurrence of cardiovascular diseases (Lee S. M. et al., 2012). In the case of kimchi, Song and Lee (2014) reported that its consumption could not be correlated to hypertension prevalence. The latter results from both sodium excess and potassium deficiency in the body; since vegetables are a major source of potassium, the high intake may neutralize the negative effects of sodium intake. Ahmadsah et al. (2015) reported that salt concentrations ranging from 1.0 to $2.1 \%$ had no effect on $\mathrm{pH}$ value, total titratable acidity, viable cell and coliform counts as well as the composition of the LAB microecosystem. The latter was reported to consist of Lb. sakei, Ln. gelidum, $L n$. lactis, Ln. mesenteroides, W. confusa, and W. soli in all cases.

Occurrence of $\mathrm{LAB}$ in the raw materials used for kimchi preparation was also studied to some extent. Green onion was reported to contain Weissella spp. Leuconostoc spp. and Lactococcus spp. (Jung et al., 2012). Moreover, Kim et al. (2004) reported that green onion was the main source of $W$. kimchi. Lactobacillus spp., Leuconostoc spp., and Weissella spp. were reported as present in garlic samples (Jung et al., 2012). Interestingly, addition of garlic resulted in suppression of aerobic bacteria populations and enhancement of LAB population (Lee J. Y. et al., 2008). Finally, a significant delay of the fermentation process, especially the early period, upon addition of red pepper powder was reported by Jeong et al. (2013b) together with a higher proportion of Weissella spp. and a lower proportion of Leuconostoc spp. and Lactobacillus spp.

\section{Safety Concerns \\ Selection of More Suitable Microorganisms for Fermentation Process}

Kimchi has been in the epicenter of extensive criticism regarding both microbiological and chemical safety. This criticism has been intensified due to the recent outbreaks linked with Kimchi consumption; the first one took place in 2012 and was caused by enterotoxigenic Escherichia coli O169 while the second occurred in 2013 and was caused by norovirus GI.4 (Cho et al., 2014; Park et al., 2015). From a microbiological point of view, it has been widely accepted that lactic acid fermented foods are not a common vehicle of foodborne pathogens due to the antagonistic effect of the LAB; however, several studies as well as these outbreaks, have highlighted that such generalizations may be uncertain for reasons referring to both the raw materials and the adaptability of the pathogens (Burnett et al., 2000; Takeuchi and Frank, 2000, 2001; Beuchat, 2002; Klerks et al., 2007; Kroupitski et al., 2009, 2011; Mitra et al., 2009; Critzer and Doyle, 2010; Warriner and Namvar, 2010). Therefore, the ability of pathogenic bacteria to survive and proliferate during kimchi fermentation or storage has been studied to some extent.

Inatsu et al. (2004) assessed the survival of E. coli O157:H7, Salmonella Enteritidis, Staphylococcus aureus, and Listeria 


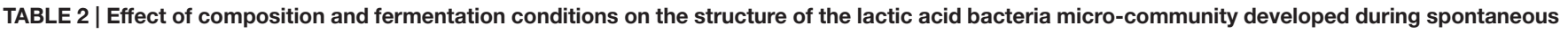
kimchi fermentation.

\begin{tabular}{|c|c|c|c|}
\hline Kimchi composition - fermentation conditions & Microbiota & Method & References \\
\hline $\begin{array}{l}\text { Chinese cabbage }(74.5 \%) \text {, radish }(13.5 \%) \text {, garlic } \\
(2.0 \%) \text {, ginger }(0.5 \%) \text {, onion }(2.0 \%) \text {, green onion } \\
(1.0 \%) \text {, red pepper powder }(3.0 \%) \text {, leek }(0.5 \%) \text {, shrimp } \\
\text { paste }(1.5 \%) \text {, anchovy paste }(0.5 \%) \text {, sucrose }(1.0 \%) \text {. } \\
\text { a. } 10^{\circ} \mathrm{C} \text { for } 4 \mathrm{~d} \text {, then reduction to }-1^{\circ} \mathrm{C} \text { over } 12 \mathrm{~h} \\
\text { b. } 15^{\circ} \mathrm{C} \text { for } 2 \mathrm{~d} \text {, then reduction to }-1^{\circ} \mathrm{C} \text { over } 24 \mathrm{~h}\end{array}$ & $\begin{array}{l}\text { Ln. carnosum, Ln. citreum, Ln. } \\
\text { gasicomitatum, Ln. gelidum, Ln. kimchii, } \\
\text { Ln. lactis, Ln. mesenteroides, Ln. inhae }{ }^{a} \text {, } \\
\text { W. cibaria, W. confusa }{ }^{a}, W . \text { koreensis, } \\
\text { Lb. curvatus }{ }^{a}, \text { Lb. pentosus, } L b ._{\text {plantarum, Lb. sakei }}\end{array}$ & $\begin{array}{l}\text { 16S-rRNA gene restriction analysis, } \\
\text { 16S-rRNA gene sequencing, specific } \\
\text { PCR, DNA-DNA hybridization }\end{array}$ & Cho et al., 2006 \\
\hline $\begin{array}{l}\text { Salted cabbage and kimchi ingredient mix } \\
\text { a. } 4^{\circ} \mathrm{C} \text { for } 30 \mathrm{~d} \\
\text { b. } 10^{\circ} \mathrm{C} \text { for } 30 \mathrm{~d}\end{array}$ & 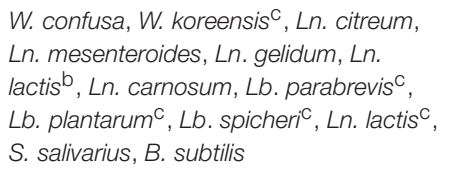 & PCR-DGGE & Hong et al., 2013 \\
\hline $\begin{array}{l}\text { Chinese cabbage } 100 \mathrm{~g} \text {, sugar } 1 \mathrm{~g} \text {, green onion } 4 \mathrm{~g} \text {, } \\
\text { garlic } 2 \mathrm{~g} \text {, ginger } 1 \mathrm{~g} \text {, red pepper powder } 2 \mathrm{~g} \text {, and } \\
\text { fermented anchovy sauce } 1.4 \mathrm{~g} \text {. } \\
\text { a. } 20^{\circ} \mathrm{C} \text { for } 20 \mathrm{~d} \\
\text { b. } 10^{\circ} \mathrm{C} \text { for } 30 \mathrm{~d}\end{array}$ & $\begin{array}{l}\text { W. confusa, Ln. citreum, Lb. brevis }{ }^{d}, L b \text {. } \\
\text { sakei, } L b . \text { curvatus, } L n \text {. lactis, } L n \\
\text { gelidum }^{C} \text {, Se. marcescens }{ }^{c}\end{array}$ & $\begin{array}{l}\text { PCR-DGGE, 16S rRNA gene } \\
\text { sequencing }\end{array}$ & Lee et al., 2005 \\
\hline $\begin{array}{l}\text { Dongchimi Radish }(3 \mathrm{~kg}) \text {, seasoning mixture }(150 \mathrm{~g}) \\
\text { containing Korean leek, garlic, and ginger }(6: 3: 1 \text {, } \\
\mathrm{w} / \mathrm{w} / \mathrm{w}) \text { and } 4.5 \text { I of } 4.0 \%(\mathrm{w} / \mathrm{v}) \text { solar salt water. } \\
\text { Fermentation at } 4^{\circ} \mathrm{C} \text { for } 100 \text { days }\end{array}$ & $\begin{array}{l}\text { W. koreensis, Lb. plantarum, Lc. } \\
\text { raffinolactis, Lc. piscium, Lc. lactis, Lb. } \\
\text { pentosus, Lb. graminis, Ln. carnosum, } \\
\text { Ln. kimchii, Ln. mesenteroides, Ln. inhae, } \\
\text { W. soli, W. cibaria, Lb. sakei, Ln. gelidum, } \\
\text { Ln. holzapfelii, Ln. lactis, Ln. } \\
\text { gasicomitatum, Ln. citreum }\end{array}$ & $\begin{array}{l}16 S \text { rRNA gene barcoded } \\
\text { pyrosequencing }\end{array}$ & Jeong et al., 2013a \\
\hline
\end{tabular}

a Only at $15^{\circ} \mathrm{C}$.

${ }^{b}$ Only at $4^{\circ} \mathrm{C}$.

${ }^{c}$ Only at $10^{\circ} \mathrm{C}$.

${ }^{d}$ Only at $20^{\circ} \mathrm{C}$.

B., Bacillus; Lb., Lactobacillus; Lc., Lactococcus; Ln., Leuconostoc; W., Weissella; Se., Serratia; S., Streptococcus.

monocytogenes in both commercial and laboratory-prepared kimchi. Both types were inoculated with 5-6 log $\mathrm{CFU} / \mathrm{g}$ of the pathogens and incubated at $10^{\circ} \mathrm{C}$ for $7 \mathrm{~d}$. It was reported that all pathogens were able to survive. Moreover, only upon prolongation of the incubation did the population of the pathogens decreased to the enumeration limit. More accurately, $S$. aureus reached enumeration limit after $12 \mathrm{~d}$, whereas $S$. Enteritidis and L. monocytogenes after $16 \mathrm{~d}$. On the contrary, E. coli O157:H7 population remained at high levels throughout the 24 days of the experiment. These results were taken into consideration by Kim Y. S. et al. (2008) who applied heat treatment $\left(85^{\circ} \mathrm{C}\right.$ for $\left.15 \mathrm{~min}\right)$ or a neutralization treatment ( $\mathrm{pH} 7$ ) at days 0 or 3 of kimchi fermentation in order to study the effect on Bacillus cereus, L. monocytogenes and S. aureus inoculated at 4-5 log CFU/g. Heat treatment at day 0 was more effective against L. monocytogenes, whereas at day 3 resulted in the complete inactivation of L. monocytogenes, significant population reduction of $B$. cereus but only marginal of $S$. aureus.

On the other hand, neutralization treatment at day 0 resulted in complete inactivation of $S$. aureus and significant decrease of $L$. monocytogenes population. However, upon neutralization treatment on day 3 , complete inactivation of L. monocytogenes and significant decrease of $S$. aureus counts were observed. This issue was also assessed by Cho et al.
(2011). In that study, the initial mixture of soongchimchae, i.e., a type of kimchi that combines fermented vegetables and meat, was spiked with 3-5 log CFU/g E. coli O157:H7 and $L$. monocytogenes and allowed to ferment at $4^{\circ} \mathrm{C}$ for $15 \mathrm{~d}$. Both $E$. coli $\mathrm{O} 157: \mathrm{H} 7$ and L. monocytogenes counts gradually decreased during fermentation and were below detection limit after 14 and 15- post fermentation days, respectively.

\section{Suitability of Raw Materials Used in Kimchi Preparation}

The high incidence of stomach cancer among Koreans raised some concerns regarding dietary habits. This high incidence was linked to the consumption of soybean paste due to aflatoxin content (Crane et al., 1970). This triggered a huge debate whether soybean paste as an ingredient and kimchi itself may be regarded as risk or protective factors (Kim et al., 1985; Messina et al., 1994; Lee et al., 1995; Kim H. J. et al., 2002; Kim J. H. et al., 2002; Nan et al., 2005; Wang et al., 2015).

From a food hygiene perspective, aflatoxin accumulation should be avoided by any possible means. Additionally, studies like the one by Park et al. (2003) that reported aflatoxin B1 and G1 gradual degradation to $80-90 \%$ after 2 months of Doenjang fermentation and $100 \%$ after 3 months of fermentation, as well as the potential of $\mathrm{LAB}$ to bind aflatoxins (Haskard et al., 


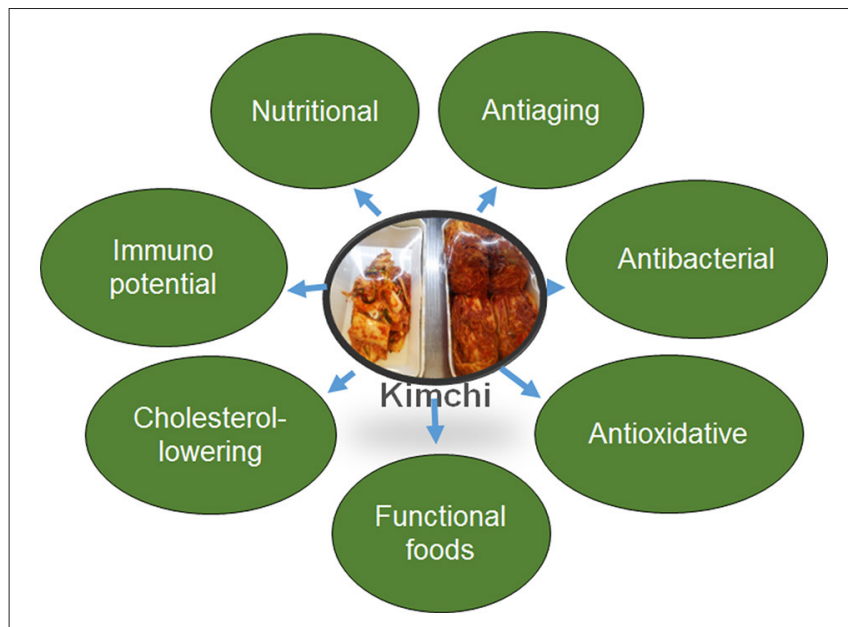

FIGURE 3 | Nutraceutical potential of Kimchi.

2001; Peltonen et al., 2001; Lahtinen et al., 2004; Bueno et al., 2007; Hernandez-Mendoza et al., 2009) and concomitantly remove them from the medium, should be further exploited. Similarly, controversial debates related to the nitrates, nitrites, ethyl carbamate, secondary, and biogenic amines content of Kimchi are currently ongoing (Kim et al., 2000; Haskard et al., 2001; Peltonen et al., 2001; Lahtinen et al., 2004; Mah et al., 2004; Bueno et al., 2007; Hernandez-Mendoza et al., 2009).

\section{Health Benefits of Kimchi Enhanced Nutritional Value}

Kimchi is recognized worldwide for the number of health claims that have been made (Figure 3). It was presented in Health Magazine in 2006 as one of the world's five healthiest foods (Lee G. I. et al., 2012; Park et al., 2014; Dharaneedharan and Heo, 2016; Tamang et al., 2016). These health benefits result from the utilization of raw materials of high nutritive value and the microbiota prevailing the fermentation. Brassicaceae vegetables have been reported to contain a number of compounds with health-promoting potential, including dietary fibers, minerals, amino acids, vitamins, carotenoids, glucosinolates, and polyphenols.

The nutritive content of Chinese cabbage [Brassica rapa $\mathrm{L}$. pekinensis (Lour.) Olsson] in particular has been extensively studied; presence of vitamins A and C, 34 amino acids with threonine, arginine, $\gamma$-aminobutyric acid, alanine, asparagine, serine and glutamic acid being quantitatively the most important, 10 mineral elements among which $\mathrm{Ca}, \mathrm{Mg}, \mathrm{K}, \mathrm{Na}$ in higher relative abundance, lutein and $\beta$-carotene as the major carotenoids has been reported with the variations in the presented values being assigned to genetic diversity, agricultural practices, harvesting stage, tissue as well as determination method (Wills and Rangga, 1996; Singh et al., 2007; Watanabe et al., 2011; Kim et al., 2014; Bhandari et al., 2015).

Therefore, the raw materials used in the preparation of kimchi result in the increased nutritional value, i.e., the high
TABLE 3 | Minimum and maximum amount ( $\mathrm{mg} / 100 \mathrm{~g}$ dry weight) of polyphenolics present in Chinese cabbage.

\begin{tabular}{lcc}
\hline Polyphenols & Seong et al., 2016 & Mattila and Hellstrom, 2007 \\
\hline Caffeic acid & nd-1.39 (0.06) & $0.54(0.046)$ \\
Sinapic acid & $\begin{array}{c}\text { (0) } \\
\text { (0.43)-8.00 } \\
\text { (0.08) }\end{array}$ & $5.2(0.44)$ \\
-Coumaric acid & $2.20(0.07)-2.89$ & $0.42(0.035)$ \\
Ferulic acid & $(0.17)$ & $1.4(0.12)$ \\
Myricetin & nd-0.47 (0.05) & \\
Vanillic acid & $0.80(0.00)-0.83$ & \\
\hline
\end{tabular}

Standard deviation is given in parenthesis; nd: not detected.

levels of vitamins such as vitamin $\mathrm{C}$, b-carotene, vitamin B complex, etc., minerals such as $\mathrm{Na}, \mathrm{Ca}, \mathrm{K}, \mathrm{Fe}$, and $\mathrm{P}$, dietary fiber, and other various functional components such as allyl compounds, gingerol, capsaicin, isothiocyanate, and chlorophyll.

\section{Rich in a Number of Bioactive Compounds}

The phytochemicals such as indole compounds, b-sitosterol, benzyl isothiocyanate, and thiocyanate are the important active compounds found in kimchi, which have been reported to possess various medicinal potentials such as antiobesity, anticancer, antioxidant, and anti-atherosclerotic properties (Park and Rhee, 2005; Ahn, 2007; Park et al., 2014). In recent years, research has been focused on the polyphenolic and glucosinolate content due to the accompanying health claims that include protective effects against various types of cancer, cardiovascular and neurodegenerative diseases (van Poppel et al., 1999; Cohen et al., 2000; Kil, 2004; Stoclet et al., 2004; Scalbert et al., 2005; Kim et al., 2007; Singh et al., 2008; Han et al., 2011; Albarracin et al., 2012; Del Rio et al., 2013; Rodríguez-Mateos et al., 2014).

In Tables 3, 4 the polyphenolic and glucosinolate content of Chinese cabbage are presented, respectively. Regarding the former, sinapic acid has been reported as the major phenolic compound whereas gluconapin, progoitrin and glucobrassicin have been reported as the major glucosinolate (Mattila and Hellstrom, 2007; Chen et al., 2008; Kim et al., 2010; Cartea et al., 2011; Hong et al., 2011; Lee et al., 2014; Seong et al., 2016). In both cases the fluctuation presented is due to the analysis of different edible parts, varieties, or cultivars.

Apart from Chinese cabbage, radish, and onion are very often added to the mix, both of which are very important sources of dietary phytochemicals such as polyphenols, thiosulfates, and anthocyanins (Manach et al., 2004; Mattila and Hellstrom, 2007; Slimestad et al., 2007; Tedesco et al., 2015). Onion is a major source of flavonoids, particularly quercetin glucosides (Srinivasan, 2014) with reported anti-inflammatory (Gerates et al., 2007; Bureau et al., 2008; Lee et al., 2010; Endale et al., 2013; Yang D. et al., 2015) and anti-carcinogenic (Djuric et al., 2012) action.

Capsaicin and piperine are the major ingredients of red and black pepper, respectively. The antioxidant activity of both 
TABLE 4 | Mimimum and maximum amounts of glucosinolates present in Chinese cabbage.

\begin{tabular}{|c|c|c|c|c|}
\hline & $\begin{array}{l}\text { (Chen et al., 2008) } \\
\text { (mg/100 g FW) }\end{array}$ & $\begin{array}{l}\text { (Kim et al., 2010) } \\
\text { (umol/g DW) }\end{array}$ & $\begin{array}{l}\text { (Lee et al., 2014) } \\
\text { (umol/g DW) }\end{array}$ & $\begin{array}{l}\text { (Hong et al., 2011) } \\
\text { (umol/g DW) }\end{array}$ \\
\hline \multicolumn{5}{|l|}{ ALIPHATIC GSs } \\
\hline Glucoalyssin & $0.19(0.02)-1.16(0.34)$ & $0.27(0.00)-3.66(0.65)$ & $0.14-0.57$ & nd-0.45 (0.05) \\
\hline Glucobrassicanapin & $0.55(0.15)-0.76(0.13)$ & $0.49(0.34)-8.08$ (6.89) & $0.16-24.78$ & $3.09(0.15)-8.18(0.39)$ \\
\hline Glucoerucin & $0.33(0.08)-1.35(0.21)$ & 0.04 (0.02)-0.94 (0.88) & & nd \\
\hline Gluconapin & 0.07 (0.02)-6.57 (1.52) & $0.40(0.06)-8.99(0.52)$ & 0.09-26.02 & nd-1.53 (0.08) \\
\hline Gluconapoleiferin & & $0.06(0.02)-2.34(2.75)$ & & \\
\hline Glucoraphanin & nd-0.40 (0.13) & $0.03(0.00)-0.49(0.48)$ & & nd \\
\hline Progoitrin & $1.44(0.51)-4.93(1.49)$ & $0.23(0.06)-3.97(2.06)$ & $0.55-4.33$ & $2.49(0.00)-5.31(0.40)$ \\
\hline Sinigrin & nd-0.44 (0.16) & $0.04(0.01)-0.15(0.03)$ & $0.09-1.96$ & \\
\hline Total & $2.79(0.72)-15.42$ (3.80) & $\begin{array}{c}1.94(0.80)-19.71 \\
(13.07)\end{array}$ & & \\
\hline \multicolumn{5}{|l|}{ INDOLIC GSs } \\
\hline 4-hydroxyglucobrassicin & $0.02(0.00)-0.05(0.01)$ & $0.02(0.00)-1.47(0.84)$ & nd-0.32 & $0.40(0.07)-1.48(0.13)$ \\
\hline 4-methoxyglucobrassicin & $0.78(0.20)-2.62(0.41)$ & $2.07(0.77)-4.83(0.62)$ & $0.21-4.35$ & $4.94(0.16)-6.08$ (0.30) \\
\hline Glucobrassicin & 4.05 (1.18)-10.31 (1.72) & $0.13(0.04)-6.81(1.72)$ & $0.10-1.66$ & $1.05(0.09)-3.80(0.08)$ \\
\hline Neoglucobrassicin & $0.53(0.10)-5.49(1.19)$ & $0.01(0.01)-0.55(0.71)$ & nd-0.47 & \\
\hline Total & $\begin{array}{c}11.67(2.02)-12.18 \\
(2.66)\end{array}$ & $2.22(0.59)-10.04$ (2.16) & & \\
\hline \multicolumn{5}{|l|}{ AROMATIC GSs } \\
\hline Gluconasturtiin & $1.37(0.34)-4.41(0.99)$ & & nd-2.61 & \\
\hline Glucoberteroin + aromatic GSs & & $0.31(0.12)-3.31(0.51)$ & & \\
\hline
\end{tabular}

Standard deviation is given in parenthesis. FW, Fresh Weight; DW, Dry Weight; nd, not detected.

substances has been well documented (Pramanik et al., 2011; Arcaro et al., 2014). Garlic is rich in organosulfur compounds known for their antiinflammatory (Kumar et al., 2013; Schäfer and Kaschula, 2014) anticarcinogenic (Wang et al., 2012; Borkowska et al., 2013; Capasso, 2013) and cardioprotective potential (Stabler et al., 2012; Ried et al., 2013). Finally, a wide range of biological activities including anticancer (Ishiguro et al., 2007; Karna et al., 2012; Yang et al., 2012; Brahmbhatt et al., 2013) and antioxidant ones (Stoilova et al., 2007) have been assigned to ginger.

\section{A Good Source of Pharmaceutical Perspectives}

The potential for weight control in both mice and humans has been adequately documented. In the first case the antiobesity action that was accompanied by several other effects such as reduction of adipose tissue weights, adipocyte size, and inflammatory response in epididymal fat tissues, regulation of serum lipid profiles, insulin, eptin, and adiponectin levels, hepatic lipogenesis were assigned to the use of Ln. mesenteroides strain DRC 0211 (Cui et al., 2015) and W. koreensis strain OK1-6 (Park et al., 2012). The potential of Ln. kimchi strain GJ2 was described by Jo et al. (2015). In that study, a high-fat and highcholesterol diet supplemented with kimchi made with the use of the aforementioned strain was fed to rats. A significant reduction of serum total cholesterol, triglyceride, low-density lipoprotein cholesterol levels, the atherogenic index, cardiac risk factor and triglyceride and total cholesterol levels in liver and epididymal adipose tissue were observed. Similar effects were observed by Kim E. K. et al. (2011).

Various researchers have indicated that consumption of kimchi on regular basis helps to decrease the level of cholesterol in the body (Kim and Lee, 1997; Kil et al., 2004). In the latter study, ingestion of fermented kimchi exhibited a series of positive effects on a variety of factors associated with metabolic syndrome, including systolic and diastolic blood pressures, percent body fat, fasting glucose, and total cholesterol, compared with the fresh kimchi suggesting that fermentation provides additional favorable effects for improving metabolic parameters. The red pepper powder used in kimchi is rich in capsaicin, which can cause loss of body fat by stimulating spinal nerves and activates the release of catecholamines in the adrenal glands of the body (Park et al., 2014). This compound increases the body metabolism and thus decreases the fat content (Yoon et al., 2004). Moreover, Kim E. K. et al. (2011) suggested that the consumption of fermented kimchi may affect obesity, lipid metabolism and inflammatory processes in human as well.

Furthermore, there are a number of health benefits with consumption of Kimchi as a part of the daily diet (Choi et al., 2015; Tamang et al., 2016). The antiaging potential of kimchi in the brain of senescence-accelerated mouse was reported by Kim J. H. et al. (2002) and using stress induced premature senescence of WI-38 human fibroblasts challenged with hydrogen peroxide was reported by Kim B. K. et al. (2011). Kimchi may have important role in delaying aging through the reduction of free radical production and increase 
in anti-oxidative enzyme activities. Similarly, kimchi also possess antibacterial potential that has been attributed to the presence of sulfur containing compounds and various LAB (Kil et al., 2004). The kimchi supplemented with Korean mistletoe extract had greater anticancer potential ( $80 \%$ inhibition ratio) than the kimchi without Korean mistletoe extract (62\%) against the HT29 human colon carcinoma cells (Kil, 2004). Likewise, different kinds of salt, natural sea salt (NS) without bittern or baked salt used to increase the taste of kimchi have been reported to increase the anticancer potential of kimchi as well (Han et al., 2009). Consumption of kimchi on a regular basis helps to increase the immune cell development and growth (Kim et al., 1997; Wu et al., 2000).

\section{CONCLUSIONS}

A number of fermented food are being eaten by the people around Korean peninsula since time immemorial. These foods have become an essential part of the Korean food culture and tradition and are enriched with a number of nutritional and medicinal values. Among the fermented foods, kimchi is most widely eaten and adored throughout the world. Its main ingredient is the napa cabbage and red chili powder together with a number of vegetables and spices enriched with functional

\section{REFERENCES}

Ahmadsah, L. S. F., Min, S. G., Han, S. K., Hong, Y., and Kim, H. Y. (2015). Effect of low salt concentrations on microbial changes during kimchi fermentation monitored by PCR-DGGE and their sensory acceptance. J. Microbiol. Biotechnol. 25, 2049-2057. doi: 10.4014/jmb.1506.06058

Ahn, S. J. (2007). The Effect of Kimchi Powder Supplement on the Body Weight Reduction of Obese Adult Women. MS thesis, Pusan National University, Busan.

Albarracin, S. L., Stab, B., Casas, Z., Sutachan, J. J., Samudio, I., Gonzalez, J., et al. (2012). Effects of natural antioxidants in neurodegenerative disease. Nutr. Neurosci. 15, 1-9. doi: 10.1179/1476830511Y.0000000028

Anthony, M. S., Clarkson, T. B., and Williams, J. K. (1998). Effects of soy isoflavones on atherosclerosis: potential mechanisms. Am. J. Clin. Nutr. 68, 1390S-1393S.

Arcaro, C. A., Gutierres, V. O., Assis, R. P., Moreira, T. F., Costa, P. I., Baviera, A. M., et al. (2014). Piperine, a natural bioenhancer, nullifies the antidiabetic and antioxidant activities of curcumin in streptozotocin-diabetic rats. PLoS ONE 9:e113993. doi: 10.1371/journal.pone.0113993

Barnes, S., Sfakianos, J., Coward, L., and Kirk, M. (1996). Soy isoflavonoids and cancer prevention. Underlying biochemical and pharmacological issues. $A d v$. Exp. Med. Biol. 401, 87-100. doi: 10.1007/978-1-4613-0399-2_7

Beuchat, L. R. (2002). Ecological factors infl uencing survival and growth of human pathogens on raw fruits and vegetables. Microbes Infect. 4, 413-423. doi: 10.1016/S1286-4579(02)01555-1

Bhandari, S. R., Jo, J. S., and Lee, J. G. (2015). Comparison of glucosinolate profiles in different tissues of nine Brassica crops. Molecules 20, 15827-15841. doi: 10.3390/molecules200915827

Borkowska, A., Knap, N., and Antosiewicz, J. (2013). Diallyl trisulfide is more cytotoxic to prostate cancer cells pc-3 than to noncancerous epithelial cell line PNT1A: A possible role of p66shc signaling axis. Nutr. Cancer. 65, 711-717. doi: 10.1080/01635581.2013.789115

Brahmbhatt, M., Gundala, S. R., Asif, G., Shamsi, S. A., and Aneja, R. (2013). Ginger phytochemicals exhibit synergy to inhibit prostate cancer cell proliferation. Nutr. Cancer. 65, 263-272. doi: 10.1080/01635581.2013.7 49925
LAB. It has various nutritional and nutraceutical potential and its quality is enhanced by manipulating the different kinds and amounts of ingredients and fermentation conditions. Although there are a number of challenges in the kimchi processing and production, however this fermented food could play a major vital role in the global food industry. Thus, kimchi can serve as one of the best healthy foods available in the world and the information on its nutraceutical and nutritional potential could increase its use.

\section{AUTHOR CONTRIBUTIONS}

JP and GD collected literature and wrote the review manuscript. JP, SP, and HS edited the manuscript. All the authors read and approved the manuscript.

\section{ACKNOWLEDGMENTS}

We are grateful to the local people of Republic of Korea for allowing us to take the photograph of different types of kimchi sold in the local markets. This study was supported by the Agricultural Research Center, Ministry of Food, Forestry, and Fisheries, Republic of Korea.
Bueno, D., Casale, C., Pizzolitto, R., Salvano, M., and Oliver, G. (2007). Physical adsorption of aflatoxin B1 by lactic acid bacteria and Saccharomyces cerevisiae: a theoretical model. J. Food Prot. 70, 2148-2154.

Bureau, G., Longpré, F., and Martinoli, M. G. (2008). Resveratrol and quercetin, two natural polyphenols, reduce apoptotic neuronal cell death induced by neuroinflammation. J. Neurosci. Res. 86, 403-410. doi: 10.1002/jnr.21503

Burnett, S. L., Chen, J., and Beuchat, L. R. (2000). Attachment of Escherichia coli $\mathrm{O} 157: \mathrm{H} 7$ to the surfaces and internal structures of apples as detected by confocal scanning laser microscopy. Appl. Environ. Microbiol. 66, 4679-4687. doi: 10.1128/AEM.66.11.4679-4687.2000

Capasso, A. (2013). Antioxidant action and therapeutic efficacy of Allium sativum L. Molecules 18, 690-700. doi: 10.3390/molecules 18010690

Cartea, M. E., Francisco, M., Soengas, P., and Velasco, P. (2011). Phenolic compounds in Brassica vegetables. Molecules 16, 251-280. doi: 10.3390/molecules 16010251

Cheigh, H. S., and Park, K. Y. (1994). Biochemical, microbiological, and nutritional aspects of kimchi (Korean fermented vegetable products). Crit. Rev. Food Sci. 34, 175-203. doi: 10.1080/10408399409527656

Chen, X., Zhu, Z., Gerenda, J., and Zimmermann, N. (2008). Glucosinolates in Chinese Brassica campestris vegetables: Chinese cabbage, purple cai-tai, choysum, pakchoi, and turnip. Hortscience 43, 571-574.

Cho, E. J. (1999). Standardization and Cancer Chemopreventive Activities of Chinese Cabbage Kimchi. Ph.D. thesis, Pusan National University, Busan, Korea.

Cho, G. Y., Lee, M. H., and Choi, C. (2011). Survival of Escherichia coli O157:H7 and Listeria monocytogenes during kimchi fermentation supplemented with raw pork meat. Food Control 22, 1253-1260. doi: 10.1016/j.foodcont.2011.01.026

Cho, J. H., Lee, D. Y., Yang, C. N., Jeon, J. I., Kim, J. H., and Han, H. U. (2006). Microbial population dynamics of kimchi, a fermented cabbage product. FEMS Microbiol. Lett. 257, 262-267. doi: 10.1111/j.1574-6968.2006.00186.x

Cho, S. H., Kim, J., Oh, K. H., Hu, J. K., Seo, J., Oh, S. S., et al. (2014). Outbreak of enterotoxigenic Escherichia coli $\mathrm{O} 169$ enteritis in schoolchildren associated with consumption of kimchi, Republic of Korea, 2012. Epidemiol. Infect. 142, 616-623. doi: 10.1017/S0950268813001477 
Cho, Y. J., Ch, W. S., Bok, S. K., Kim, M. U., Chun, C. S., and Choi, U. K. (2000). Production and separation of anti-hypertensive peptide during Chungkookjang fermentation with Paramithiotis CH-1023. J. Korean Soc. Appl. Biol. Chem. 43, 247-253.

Choi, B. (2012). Gochujang: Korean Go-to, All-In-One Magic Chile Sauce. Available online at: http://www.theawl.com/2012/01/gochujang-korean-go-toall-in-one-magic-chile-sauce (Accessed March 17, 2016).

Choi, H., Lee, N., and Paik, H. (2015). Health benefits of lactic acid bacteria isolated from kimchi, with respect to immunomodulatory effects. Food Sci. Biotechnol. 24, 783. doi: 10.1007/s10068-015-0102-3

Choi, H. S., Lee, J. S., Moon, G. S., and Park, G. Y. (1990). Antioxidative characteristics of fermented soybean sauce on the oxidation of fatty acid mixture. Korean J. Food Sci. Technol. 22, 332-336.

Choi, J. H., Chung, M. J., Jeong, D. Y., and Oh, D. H. (2014). Immunostimulatory activity of isoflavone-glycosides and ethanol extract from a fermented soybean product in human primary immune cells. J. Med. Food 17, 1113-1121. doi: 10.1089/jmf.2013.3040

Cohen, J. H., Kristal, A. R., and Stanford, J. L. (2000). Fruit and vegetable intakes and prostate cancer risk. J. Nat. Cancer Inst. 92, 61-68. doi: 10.1093/jnci/92.1.61

Codex Alimentarius Commission (Codex) (2001). Codex Standard for Kimchi. Codex Standard 223. Rome: Food and Agriculture Organization of the United Nations.

Crane, P. S., Rhee, S. U., and Seel, D. J. (1970). Experience with 1079 cases of cancer of the stomach seen in Korea from 1962 to 1968. Am. J. Surg. 120, 747-751. doi: 10.1016/S0002-9610(70)80041-1

Critzer, F. J., and Doyle, M. P. (2010). Microbial ecology of foodborne pathogens associated with produce. Curr. Opin. Biotechnol. 21, 125-130. doi: 10.1016/j.copbio.2010.01.006

Cui, M., Kim, H. Y., Lee, K. H., Jeong, J. K., Hwang, J. H., Yeo, K. Y., et al. (2015). Antiobesity effects of kimchi in diet-induced obese mice. J. Ethnic Foods 2, 137-144. doi: 10.1016/j.jef.2015.08.001

Del Rio, D., Rodriguez-Mateos, A., Spencer, J. P. E., Tognolini, M., Borges, G., and Crozier, A. (2013). Dietary (poly)phenolics in human health: structures, bioavailability, and evidence of protective effects against chronic diseases. Antioxid. Redox Signal. 18, 1818-1892. doi: 10.1089/ars.2012.4581

Demir, N., Bahceci, K. S., and Acar, J. (2006). The effects of different initial Lactobacillus plantarum concentrations on some properties of fermented carrot juice. J. Food Process. Preserv. 30, 352-363. doi: 10.1111/j.17454549.2006.00070.x

Dharaneedharan, S., and Heo, M. S. (2016). Korean Traditional fermented foods a potential resource of beneficial microorganisms and their applications. J. Life Sci. 26, 496-502. doi: 10.5352/JLS.2016.26.4.496

Di Cagno, R., Coda, R., Angelis, M. D., and Gobbetti, M. (2013). Exploitation of vegetables and fruits through lactic acid fermentation. Food Microbiol. 33, 1-10. doi: 10.1016/j.fm.2012.09.003

Djuric, Z., Severson, R. K., and Kato, I. (2012). Association of dietary quercetin with reduced risk of proximal colon cancer. Nutr. Cancer 64, 351-360. doi: 10.1080/01635581.2012.658950

Endale, M., Park, S. C., Kim, S., Kim, S. H., Yang, Y., Cho, J. Y., et al. (2013). Quercetin disrupts tyrosine-phosphorylated phosphatidylinositol 3-kinase and myeloid differentiation factor-88 association, and inhibits MAPK/AP-1 and IKK/NF-кB-induced inflammatory mediators production in RAW 264.7 cells. Immunobiology 218, 1452-1467. doi: 10.1016/j.imbio.2013.04.019

Endrizzi, I., Pirretti, G., Calo, D. G., and Gasperi, F. (2009). A consumer study of fresh juices containing berry fruits. J. Sci. Food Agric. 89, 1227-1235. doi: $10.1002 /$ jsfa. 3580

FAO (1998). Fermented Fruits and Vegetables-A Global Perspective, Vol. 134. Rome: FAO Agricultural Services Bulletin.

Gerates, L., Moonen, H. J. J., Brauers, K., Wouters, E. F. M., Bast, A., and Hageman, G. J. (2007). Dietary flavones and flavonols are inhibitor of poly (ADP-ribose) polymerase-1 in pulmonary epithelial cells. J. Nutr. 137, 2190-2195.

Han, B. J., Han, B. R., and Whang, H. S. (1998). Kanjang and Doenjang, in One Hundred Korean Foods That Koreans Must Know. Seoul: Hyun Am Sa.

Han, G. J., Son, A. R., Lee, S. M., Jung, J. K., Kim, S. H., and Park, K. Y. (2009). Improved quality and increased in vitro anticancer effect of kimchi by using natural sea salt without bittern and baked (Guwun) salt. J. Korean Soc. Food Sci. Nutr. 38, 996-1002. doi: 10.3746/jkfn.2009.38.8.996
Han, W., Hu, W., and Lee, Y. M. (2011). Anti-cancer activity of human colon cancer (HT-29) cell line from different fraction of Zanthoxylum schnifolium fruits. Korean J. Pharmacogn. 42, 282-287.

Haskard, C., El-Nezami, H., Kankaanpää, P., Salminen, S., and Ahokas, J. (2001). Surface binding of aflatoxin B1 by lactic acid bacteria. Appl. Environ. Microbiol. 67, 3086-3091. doi: 10.1128/AEM.67.7.3086-3091.2001

Hernandez-Mendoza, A., Garcia, H. S., and Steele, J. L. (2009). Screening of Lactobacillus casei strains for their ability to bind aflatoxin B1. Food Chem. Toxicol. 47, 1064-1068. doi: 10.1016/j.fct.2009.01.042

Hong, E., Kim, S. J., and Kim, G. H. (2011). Identification and quantitative determination of glucosinolates in seeds and edible parts of Korean Chinese cabbage. Food Chem. 128, 1115-1120. doi: 10.1016/j.foodchem.2010.11.102

Hong, Y., Yang, H. S., Chang, H. C., and Kim, H. Y. (2013). Comparison of bacterial community changes in fermenting kimchi at two different temperatures using a denaturing gradient gel electrophoresis analysis. J. Microbiol. Biotechnol. 23, 76-84. doi: 10.4014/jmb.1210.10002

Hong-beum, A. (2004). Ganjang and Doenjang: Traditional Fermented Seasonings, Vol. 18. Koreana 62-67. Available online at: http://koreana.kf.or.kr/view.asp?article_id=5423 (Accessed March 17, 2016).

Inatsu, Y., Bari, M. L., Kawasaki, S., and Isshiki, K. (2004). Survival of Escherichia coli O157:H7, Salmonella enteritidis, Staphylococcus aureus, and Listeria monocytogenes in Kimchi. J. Food Prot. 67, 1497-1500.

Ishiguro, K., Ando, T., Maeda, O., Ohmiya, N., Niwa, Y., Kadomatsu, K., et al. (2007). Ginger ingredients reduce viability of gastric cancer cells via distinct mechanisms. Biochem. Biophy. Res. Commun. 362, 218-223. doi: 10.1016/j.bbrc.2007.08.012

Jang, D. J., Chung, K. R., Yang, H. J., Kim, K. S., and Kwon, D. Y. (2015). Discussion on the origin of kimchi, representative of Korean unique fermented vegetables. J. Ethnic Foods 2, 126-136. doi: 10.1016/j.jef.2015.08.005

Jang, S. J., Kim, Y. J., Park, J. M., and Park, Y. S. (2011). Analysis of microflora in gochujang, Korean traditional fermented food. Food Sci. Biotechnol. 20, 1435-1440. doi: 10.1007/s10068-011-0197-0

Jeon, M. S., Sohn, K. H., Chae, S. H., Park, H. K., and Jeon, H. J. (2002). Color characteristics of Korean traditional soy sauces prepared under different processing conditions. J. Korean Soc. Food Sci. Nutr. 31, 32-38. doi: 10.3746/jkfn.2002.31.1.032

Jeong, S. H., Jung, J. Y., Lee, S. H., Jin, H. M., and Jeon, C. O. (2013a). Microbial succession and metabolite changes during fermentation of dongchimi, traditional Korean watery kimchi. Int. J. Food Microbiol. 164, 46-53. doi: 10.1016/j.ijfoodmicro.2013.03.016

Jeong, S. H., Lee, H. J., Jung, J. Y., Lee, S. H., Seo, H. Y., Park, W. S., et al. (2013b). Effects of red pepper powder on microbial communities and metabolites during kimchi fermentation. Int. J. Food Microbiol. 160, 252-259. doi: 10.1016/j.ijfoodmicro.2012.10.015

Jo, S. Y., Choi, E. A., Lee, J. J., and Chang, H. C. (2015). Characterization of starter kimchi fermented with Leuconostoc kimchii GJ2 and its cholesterol-lowering effects in rats fed a high-fat and high-cholesterol diet. J. Sci. Food Agric. 95, 2750-2756. doi: 10.1002/jsfa.7018

Jung, J. Y., Lee, S. H., and Jeon, C. O. (2014). Kimchi microflora: history, current status, and perspectives for industrial kimchi production. Appl. Microbiol. Biotechnol. 98, 2385-2393. doi: 10.1007/s00253-014-5513-1

Jung, J. Y., Lee, S. H., Jin, H. M., Hahn, Y., Madsen, E. L., and Jeon, C. O. (2013). Metatranscriptomic analysis of lactic acid bacterial gene expression during kimchi fermentation. Int. J. Food Microbiol. 163, 171-179. doi: 10.1016/j.ijfoodmicro.2013.02.022

Jung, J. Y., Lee, S. H., Lee, S. H., and Jeon, C. O. (2012). Complete genome sequence of Leuconostoc mesenteroides subsp. mesenteroides strain J18, isolated from kimchi. J. Bacteriol. 194, 730. doi: 10.1128/JB.06498-11

Kabak, B., and Dobson, A. D. (2011). An introduction to the traditional fermented foods and beverages of Turkey. Crit. Rev. Food Sci. Nutr. 51, 248-260. doi: 10.1080/10408390903569640

Kang, M. J., Kim, S. H., Joo, H. K., Lee, G. S., and Yim, M. H. (2000). Isolation and identification of microorganisms producing the soy protein-hydrolyzing enzyme from traditional mejus. J. Korean Soc. Agric. Chem. Biotechnol. 43, 86-94.

Kang, S. M., Lee, C. S., Yoo, C. K., and Seo, W. S. (1998). Purification and characterization of fibrinolytic enzyme excreted by Bacillus subtilis K-54 
isolated from Chung Guk Jang. Korean J. Appl. Microbiol. Biotechnol. 26, 507-515.

Karna, P., Chagani, S., Gundala, S. R., Rida, P. C., Asif, G., Sharma, V., et al. (2012). Benefits of whole ginger extract in prostate cancer. Br. J. Nutr. 107, 473-484. doi: $10.1017 /$ S0007114511003308

Kil, J. H. (2004). Studies on Development of Cancer Preventive and Anticancer Kimchi and Its Anticancer Mechanism. Ph.D. thesis, Pusan National University, Busan.

Kil, J. H., Jung, K. O., Lee, H. S., Hwang, I. K., Kim, Y. J., and Park, K. Y. (2004). Effects of kimchi on stomach and colon health of Helicobacter pylori-infected volunteers. J. Food Sci. Nutri. 9, 161-166. doi: 10.3746/jfn.2004.9.2.161

Kim, B. K., Park, K. Y., Kim, H. Y., Ahn, S. C., and Cho, E. J. (2011). Anti-aging effects and mechanisms of kimchi during fermentation under stress-induced premature senescence cellular system. Food Sci. Biotechnol. 20, 643-649. doi: 10.1007/s10068-011-0091-9

Kim, E. K., An, S. Y., Lee, M. S., Kim, T. H., Lee, H. K., Hwang, W. S., et al. (2011). Fermented kimchi reduces body weight and improves metabolic parameters in overweight and obese patients. Nutr. Res. 31, 436-443. doi: 10.1016/j.nutres.2011.05.011

Kim, H. J., Chang, W. K., Kim, M. K., Lee, S. S., and Choi, B. Y. (2002). Dietary factors and gastric cancer in Korea: a case-control study. Int. J. Cancer 97, 531-535. doi: 10.1002/ijc.10111

Kim, H. W., Choi, J. H., Choi, Y. S., Han, D. J., Kim, H. Y., Lee, M. A., et al. (2011). Effects of soybean sauce and pre-rigor muscle on physicochemical properties of frozen Hanwoo patties. Korean J. Food Sci. Ani. Resour. 31, 19-26. doi: 10.5851/kosfa.2011.31.1.019

Kim, J., Bang, J., Beuchat, L. R., Kim, H., and Ryu, J. H. (2012). Controlled fermentation of kimchi using naturally occurring antimicrobial agents. Food Microbiol. 32, 20-31. doi: 10.1016/j.fm.2012.05.007

Kim, J. H., Ryu, J. D., Lee, H. G., and Park, J. H. (2002). The effect of kimchi on production of free radicals and antioxidative enzyme activities in the brain of SAM. J. Korean Soc. Food Sci. Nutr. 31, 117-123. doi: $10.3746 / \mathrm{jkfn} .2002 .31 .1 .117$

Kim, J. J., Maria-John, K. M., Moon, H. K., Jin, K., Enkhtaivan, G., and Kim, D. H. (2014). Morphological and biochemical variation of Chinese cabbage (Brassica rapa spp. pekinensis) cultivated using different agricultural practices. J. Food Comp. Anal. 36, 12-23. doi: 10.1016/j.jfca.2014.06.009

Kim, J. K., Chu, S. M., Kim, S. J., Lee, D. J., Lee, S. Y., Lim, S. H., et al. (2010). Variation of glucosinolates in vegetable crops of Brassica rapa L. ssp. pekinensis. Food Chem. 119, 423-428. doi: 10.1016/j.foodchem.2009.08.051

Kim, J. P., Park, J. G., Lee, M. D., Han, M. D., Park, S. T., Lee, B. H., et al. (1985). Co-carcinogenic effects of several Korean foods on gastric cancer induced by N-Methyl- N'-Nitro-N-Nitrosoguanidine in rats. Jpn. J. Surg. 15, 427-437. doi: 10.1007/BF02470087

Kim, J. Y., and Lee, Y. S. (1997). The effects of kimchi intake on lipid contents of body and mitogen response of spleen lymphocytes in rats. J. Korean Soc. Food Sci. Nutr. 26, 1200-1207.

Kim, M., and Chun, J. (2005). Bacterial community structure in kimchi, a Korean fermented vegetable food, as revealed by $16 \mathrm{~S}$ rRNA gene analysis. Int. J. Food Microbiol. 103, 91-96. doi: 10.1016/j.ijfoodmicro.2004.11.030

Kim, M. J., Kwon, M. J., Song, Y. O., Lee, E. K., Yoon, H. J., and Song, Y. S. (1997). The effects of kimchi on hematological and immunological parameters in vivo and in vitro. J. Korean Soc. Food Sci. Nutr. 26, 1208-1214.

Kim, N. Y., Song, E. J., Kwon, D. Y., Kim, H. P., and Heo, M. Y. (2008). Antioxidant and antigenotoxic activities of Korean fermented soybean. Food Chem. Toxicol. 46, 1184-1189. doi: 10.1016/j.fct.2007.12.003

Kim, T. W., Lee, J. H., Kim, S. E., Park, M. H., Chang, H. C., and Kim, H. Y. (2009). Analysis of microbial communities in doenjang, a Korean fermented soybean paste, using nested PCR-denaturing gradient gel electrophoresis. Int. J. Food Microbiol. 131, 265-271. doi: 10.1016/j.ijfoodmicro.2009.03.001

Kim, Y., Cho, J. Y., Kuk, J. H., Moon, J. H., Cho, J. I., Kim, Y. C., et al. (2004). Identification and antimicrobial activity of phenylacetic acid produced by Bacillus licheniformis isolated from fermented soybean, Chungkook-Jang. Curr. Microbiol. 48, 312-317. doi: 10.1007/s00284-003-4193-3

Kim, Y. K. L., Koh, E., Chung, H. J., and Kwon, H. (2000). Determination of ethyl carbamate in some fermented Korean foods and beverage. Food Addit. Contam. 17, 469-475. doi: 10.1080/02652030050034055
Kim, Y. S., Zheng, Z. B., and Shin, D. H. (2008). Growth inhibitory effects of kimchi (Korean traditional fermented vegetable product) against Bacillus cereus, Listeria monocytogenes, and Staphylococcus aureus. J. Food Prot. 71, 325-332.

Kim, Y. T., Kim, B. K., and Park, K. Y. (2007). Antimutagenic and anticancer effects of leaf mustard and leaf mustard kimchi. J. Food Sci. Nutr. 12, 84-88. doi: $10.3746 /$ ifn.2007.12.2.084

Klerks, M. M., Franz, E., van Gent-Pelzer, M., Zijlstra, C., and van Bruggen, A. H. C. (2007). Differential interaction of Salmonella enterica serovars with lettuce cultivars and plant-microbe factors influencing the colonization efficiency. ISME J. 1, 620-631. doi: 10.1038/ismej.2007.82

Koo, O. K., Lee, S. J., Chung, K. R., Jang, D. J., Yang, H. J., and Kwon, D. Y. (2016). Korean traditional fermented fish products: jeotgal. J. Ethnic Food 3, 107-116. doi: 10.1016/j.jef.2016.06.004

Kroupitski, Y., Golberg, D., Belausov, E., Pinto, R., Swartzberg, D., Granot, D., et al. (2009). Internalization of Salmonella enterica in leaves is induced by light and involves chemotaxis and penetration through open stomata. Appl. Environ. Microbiol. 75, 6076-6086. doi: 10.1128/AEM.010 84-09

Kroupitski, Y., Pinto, R., Belausov, E., and Sela, S. (2011). Distribution of Salmonella Typhimurium in romaine lettuce leaves. Food Microbiol. 28, 990-997. doi: 10.1016/j.fm.2011.01.007

Kumar, R., Chhatwal, S., Arora, S., Sharma, S., Singh, J., Singh, N., et al. (2013). Antihyperglycemic, antihyperlipidemic, anti-inflammatory and adenosine deaminase-lowering effects of garlic in patients with type 2 diabetes mellitus with obesity. Diabetes Metab. Syndr. Obes. 6, 49-56. doi: 10.2147/DMSO.S38888

Kwon, D. Y., Daily, J. W. III, Kim, H. J., and Park, S. (2010). Antidiabetic effects of fermented soybean products on type 2 diabetes. Nutr. Res. 30, 1-13. doi: 10.1016/j.nutres.2009.11.004

Kwon, D. Y., Hong, S. M., Ahn, I. S., Kim, M. J., Yang, H. J., and Park, S. (2011). Isoflavonoids and peptides from meju, long-term fermented soybeans, increase insulin sensitivity and exert insulinotropic effects in vitro. Nutrition 27, 244-252. doi: 10.1016/j.nut.2010.02.004

Lahtinen, S. J., Haskard, C. A., Ouwehand, A. C., Salminen, S. J., and Ahokas, J. T. (2004). Binding of aflatoxin B1 to cell wall components of Lactobacillus rhamnosus strain GG. Food Addit. Contam. 21, 158-164. doi: $10.1080 / 02652030310001639521$

Lee, D., Kim, S., Cho, J., and Kim, J. (2008). Microbial population dynamics and temperature changes during fermentation of kimjang kimchi. J. Microbiol. 46, 590-593. doi: 10.1007/s12275-008-0156-5

Lee, G. I., Lee, H. M., and Lee, C. H. (2012). Food safety issues in industrialization of traditional Korean foods. Food Control 24, 1-5. doi: 10.1016/j.foodcont.2011.09.014

Lee, H., Yoon, H., Ji, Y., Kim, H., Park, H., Lee, J., et al. (2011). Functional properties of Lactobacillus strains isolated from kimchi. Int. J. Food Microbiol. 145, 155-161. doi: 10.1016/j.ijfoodmicro.2010.12.003

Lee, J. K., Park, B. J., Yoo, K. Y., and Ahn, Y. O. (1995). Dietary factors and stomach cancer: a case-control study in Korea. Int. J. Epidemiol. 24, 33-41. doi: 10.1093/ije/24.1.33

Lee, J. S., Chun, C. O., Jung, M. C., Kim, W. S., Kim, H. J., Hector, M., et al. (1997). Classification of isolates originating from kimchi using carbon-source utilization patterns. J. Microbiol. Biotechnol. 7, 68-74.

Lee, J. S., Heo, G. Y., Lee, J. W., Oh, Y. J., Park, J. A., Park, Y. H., et al. (2005). Analysis of kimchi microflora using denaturing gradient gel electrophoresis. Int. J. Food Microbiol. 102, 143-150. doi: 10.1016/j.ijfoodmicro.2004.12.010

Lee, J. Y., Choi, M. K., and Kyung, K. H. (2008). Reappraisal of stimulatory effect of garlic on kimchi fermentation. Korean J. Food Sci. Technol. 40, 479-484.

Lee, K. M., Hwang, M. K., Lee, D. E., Lee, K. W., and Lee, H. J. (2010). Protective effect of quercetin against arsenite-induced COX-2 expression by targeting PI3K in rat liver epithelial cells. J. Agric. Food Chem. 58, 5815-5820. doi: $10.1021 / \mathrm{jf} 903698 \mathrm{~s}$

Lee, M. E., Jang, J. Y., Lee, J. H., Park, H. W., Choi, H. J., and Kim, T. W. (2015). Starter cultures for kimchi fermentation. J. Microbiol. Biotechnol. 25, 559-568. doi: $10.4014 / \mathrm{jmb} .1501 .01019$

Lee, M. K., Chun, J. H., Byeon, D. H., Chung, S. O., Park, S. U., Park, S., et al. (2014). Variation of glucosinolates in 62 varieties of Chinese cabbage (Brassica 
rapa L. spp. pekinensis) and their antioxidant activity. LWT Food Sci. Technol. 58, 93-101. doi: 10.1016/j.lwt.2014.03.001

Lee, S. M., Cho, Y., Chung, H. K., Shin, D. H., Ha, W. K., Lee, S. C., et al. (2012). Effects of kimchi supplementation on blood pressure and cardiac hypertrophy with varying sodium content in spontaneously hypertensive rats. Nutr. Res. Pract. 6, 315-321. doi: 10.4162/nrp.2012.6.4.315

Lim, S. Y., Park, K. Y., and Rhee, S. H. (1999). Anticancer effect of doenjang in in vitro sulforhodamine B (SRB) assay. J. Korean Soc. Food Sci. Nutr. 28, 240-245.

Lim, S. Y., Rhee, S. H., Park, K. Y., Yun, H. S., and Lee, W. H. (2004). Inhibitory effect of methanol extracts and solvent fractions from doenjang on mutagenicity using in vitro SOS chromotest and in vivo Drosophila mutagenic system. J. Korean Soc. Food Sci. Nutr. 33, 1432-1438. doi: 10.3746/jkfn.2004.33.9.1432

Lim, Y. S., Park, K. N., Bae, M. J., and Lee, S. H. (2001). Antimicrobial effects of ethanol extracts of Pinus densiflora Sieb. et Zucc on lactic acid bacteria. J. Korean Soc. Food. Sci. Nutr. 30, 1158-1163.

Mah, J. H., Kim, Y. J., No, H. K., and Hwang, H. J. (2004). Determination of biogenic amines in Kimchi, Korean traditional fermented vegetable products. Food Sci. Biotechnol. 13, 826-829.

Manach, C., Scalbert, A., Morand, C., Rémésy, C., and Jimenez, L. (2004). Polyphenols: food sources and bioavailability. Am. J. Clin. Nutr. 79, 727-747.

Mattila, P., and Hellstrom, J. (2007). Phenolic acids in potatoes, vegetables, and some of their products. J. Food Comp. Anal. 20, 152-160. doi: 10.1016/j.jfca.2006.05.007

Messina, M. J., Persky, V., Setchell, K. D., and Barnes, S. (1994). Soy intake and cancer risk: a review of the in vitro and in vivo data. Nutr. Cancer 21, 113-131. doi: 10.1080/01635589409514310

Mitra, R., Cuesta-Alonso, E., Wayadande, A., Talley, J., Gilliland, S., and Fletcher, J. (2009). Effect of route of introduction and host cultivar on the colonization, internalization, and movement of the human pathogen Escherichia coli O157:H7 in spinach. J. Food Prot. 72, 1521-1530.

Nakajima, N., Nozaki, N., Ishihara, K., Ishikawa, A., and Tsuji, H. (2005). Analysis of isoflavone content in tempeh, a fermented soybean, and preparation of a new isoflavone-enriched tempeh. J. Biosci. Bioeng. 100, 685-687. doi: $10.1263 / \mathrm{jbb} .100 .685$

Nam, Y. R., Won, S. B., Chung, Y. S., Kwak, C. S., and Kwon, Y. H. (2015). Inhibitory effects of Doenjang, Korean traditional fermented soybean paste, on oxidative stress and inflammation in adipose tissue of mice fed a high-fat diet. Nutr. Res. Pract. 9, 235-241. doi: 10.4162/nrp.2015.9.3.235

Nan, H. M., Park, J. W., Song, Y. J., Yun, H. Y., Park, J. S., Hyun, T., et al. (2005). Kimchi and soybean pastes are risk factors of gastric cancer. World J. Gastroenterol. 11, 3175-3181. doi: 10.3748/wjg.v11.i21.3175

Oh, S. H., Park, K. W., Daily, J. W., and Lee, Y. E. (2014). Preserving the legacy of healthy Korean food. J. Med. Food 17, 1-5. doi: 10.1089/jmf.2014.1701.ed

Park, H. K., Gil, B., and Kim, J. K. (2002). Characteristics of taste components of commercial soybean paste. Food Sci. Biotechnol. 11, 376-379.

Park, J. A., Tirupathi Pichiah, P. B., Yu, J. J., Oh, S. H., Daily, J. W. III, and Cha, Y.S. (2012). Antiobesity effect of kimchi fermented with Weissella koreensis OK1-6 as starter in high-fat diet-induced obese C57BL/6J mice. J. Appl. Microbiol. 113, 1507-1516. doi: 10.1111/jam.12017

Park, J. H., Jung, S., Shin, J., Lee, J. S., Joo, I. S., and Lee, D. Y. (2015). Three gastroenteritis outbreaks in South Korea caused by the consumption of kimchi tainted by norovirus GI.4. Foodborne Pathog. Dis. 12, 221-227. doi: 10.1089/fpd.2014.1879

Park, K. Y., and Cheigh, H. S. (2003). "Kimchi," in Handbook of Vegetable Preservation and Processing, eds Y. H. Hui, S. Ghazala, D. M. Graham, K. D. Murrell, and W. K. Nip (Broken Sound Parkway NW: CRC Press), 189-222.

Park, K. Y., Jeong, J. K., Lee, Y. E., and Daily, J. W. (2014). Health benefits of kimchi (Korean fermented vegetables) as a probiotic food. J. Med. Food 17, 6-20. doi: $10.1089 / \mathrm{jmf} .2013 .3083$

Park, K. Y., Jung, K. O., Rhee, S. H., and Choi, Y. H. (2003). Antimutagenic effects of doenjang (Korean fermented soypaste) and its active compounds. Mutat. Res. 523-524, 43-53. doi: 10.1016/S0027-5107(02)00320-2

Park, K. Y., and Rhee, S. H. (2005). "Functional foods from fermented vegetable products: kimchi (Korean fermented vegetables) and functionality," in Asian Functional Foods, eds J. Shi, C. T. Ho, and F. Shahidi (Boca Raton, FL: CRC Press, Inc.), 341-380.
Park, W. S., Koo, Y. C., Ahn, B. H., and Choi, S. (1994). Process Standardization of Kimchi Manufacturing. Seoul: Korea Food Research Institute.

Peltonen, K., El-Nezami, H., Haskard, C., Ahokas, J., and Salminen, S. (2001). Aflatoxin B1 binding by dairy strains of lactic acid bacteria and bifidobacteria. J. Dairy Sci. 84, 2152-2156. doi: 10.3168/jds.S0022-0302(01)74660-7

Pramanik, K. C., Boreddy, S. R., and Srivastava, S. K. (2011). Role of mitochondrial electron transport chain complexes in capsaicin mediated oxidative stress leading to apoptosis in pancreatic cancer cells. PLoS ONE 6:e20151. doi: 10.1371/journal.pone.0020151

Prester, L. (2011). Biogenic amines in fish, fish products and shellfish: a review. Food Addit. Contam. Part A Chem. Anal. Control Expo. Risk. Assess. 28, 1547-1560. doi: 10.1080/19440049.2011.600728

Ra, K. S., Oh, S. H., Kim, J. M., and Suh, H. J. (2004). Isolation of fibrinolytic enzyme and $\beta$-glucosidase producing strains from doenjang and optimum conditions of enzyme production. J. Korean Soc. Food Sci. Nutr. 33, 439-442. doi: $10.3746 / \mathrm{jkfn} .2004 .33 .2 .439$

Ried, K., Toben, C., and Fakler, P. (2013). Effect of garlic on serum lipids: an updated metaanalysis. Nutr. Rev. 71, 282-299. doi: 10.1111/nure.12012

Rodríguez-Mateos, A., Vauzour, D., Krueger, C. G., Shanmuganayagam, D., Reed, J., Calani, L., et al. (2014). Bioavailability, bioactivity and impact on health of dietary flavonoids and related compounds: an update. Arch. Toxicol. 88, 1803-1853. doi: 10.1007/s00204-014-1330-7

Rolle, R., and Satin, M. (2002). Basic requirements for the transfer of fermentation technologies to developing countries. Int. J. Food Microbiol. 75, 181-187. doi: 10.1016/S0168-1605(01)00705-X

Ryu, B. H., Sim, G. S., Lee, J. H., and Ha, W. K. (2012). Plant Originated Lactobacillus plantarum DSR CK10, DSR M2 to Keep Freshness and Use Thereof. Korean patent. 10-1124056.

Scalbert, A., Manach, C., Morand, C., Rémésy, C., and Jiménez, L. (2005). Dietary polyphenols and the prevention of diseases. Crit. Rev. Food Sci. Nutr. 45, 287-306. doi: 10.1080/1040869059096

Schäfer, G., and Kaschula, C. H. (2014). The immunomodulation and anti-inflammatory effects of garlic organosulfur compounds in cancer chemoprevention. Anticancer Agents. Med. Chem. 14, 233-240. doi: $10.2174 / 18715206113136660370$

Seong, G. U., Hwang, I. W., and Chung, S. K. (2016). Antioxidant capacities and polyphenolics of Chinese cabbage (Brassica rapa L. ssp. Pekinensis) leaves. Food Chem. 199, 612-618. doi: 10.1016/j.foodchem.2015.12.066

Shim, S. L., Ryo, K. Y., Kim, W., Jun, S. N., Seo, H. Y., Han, K. J., et al. (2008). Physicochemical characteristics of medicinal herbs Ganjang. Korean J. Food Preserv. 15, 243-252.

Shin, D., and Jeong, D. Y. (2015). Korean traditional fermented soybean products (Jang). J. Ethnic Foods 2, 1-6. doi: 10.1016/j.jef.2015.02.002

Singh, J., Upadhyay, A. K., Prasad, K., Bahadur, A., and Rai, M. (2007). Variability of carotenes, vitamin C, E and phenolics in Brassica vegetables. J. Food Comp. Anal. 20, 106-112. doi: 10.1016/j.jfca.2006.08.002

Singh, M., Arseneault, M., Sanderson, T., Murthy, V., and Ramassamy, C. (2008). Challenges for research on polyphenols from foods in Alzheimer's disease: bioavailability, metabolism, and cellular and molecular mechanisms. J. Agric. Food Chem. 56, 4855-4873. doi: 10.1021/jf0735073

Slimestad, R., Fossen, T., and Vagen, I. M. (2007). Onions: a source of unique dietary flavonoids. J. Agric. Food Chem. 55, 10067-10080. doi: $10.1021 / \mathrm{jf} 0712503$

Song, H. J., and Lee, H. J. (2014). Consumption of kimchi, a salt fermented vegetable, is not associated with hypertension prevalence J. Ethnic Foods 1, 8-12. doi: 10.1016/j.jef.2014.11.004

Srinivasan, K. (2014). Antioxidant potential of spices and their active constituents. Crit. Rev. Food Sci. 54, 352-372. doi: 10.1080/10408398.2011.585525

Stabler, S. N., Tejani, A. M., Huynh, F., and Fowkes, C. (2012). Garlic for the prevention of cardiovascular morbidity and mortality in hypertensive patients. Cochrane Database Syst. Rev. 8:CD007653. doi: 10.1002/14651858.cd007653.pub2

Stoclet, J. C., Chataigneau, T., Ndiaye, M., Oak, M. H., El Bedoui, J., Chataigneau, M., et al. (2004). Vascular protection by dietary polyphenols. Eur. J. Pharmacol. 500, 299-313. doi: 10.1016/j.ejphar.2004.07.034

Stoilova, I., Krastanov, A., Stoyanova, A., Denev, P., and Gargovaa, S. (2007). Antioxidant activity of a ginger extract (Zingiber officinale). Food Chem. 102, 764-770. doi: 10.1016/j.foodchem.2006.06.023 
Su, C. L., Wu, C. J., Chen, F. N., Wang, B. J., Sheu, S. R., and Won, S. J. (2007). Supernatant of bacterial fermented soybean induces apoptosis of human hepatocellular carcinoma Hep $3 \mathrm{~B}$ cells via activation of caspase 8 and mitochondria. Food Chem. Toxicol. 45, 303-314. doi: 10.1016/j.fct.2006. 07.031

Surh, J., Kim, Y. H. L., and Kwon, H. (2008). "Korean fermented foods, Kimchi and Doenjang," in Handbook of Fermented Functional Foods, ed E. R. Farnworth (Boca Raton, FL; London: CRC press), 333-351.

Swain, M. R., Anandharaj, M., Ray, R. C., and Rani, R. P. (2014). Fermented fruits and vegetables of Asia: a potential source of probiotics. Biotechnol. Res. Int. 2014:250424. doi: 10.1155/2014/250424

Takeuchi, K., and Frank, J. F. (2000). Penetration of Escherichia coli O157:H7 into lettuce tissues as affected by inoculum size and temperature and the effect of chlorine treatment on cell viability. J. Food. Prot. 63, 434-440.

Takeuchi, K., and Frank, J. F. (2001). Quantitative determination of the role of lettuce leaf structures in protecting Escherichia coli O157:H7 from chlorine disinfection. J. Food Prot. 64, 147-151.

Tamang, J. P., Watanabe, K., and Holzapfel, W. H. (2016). Review: diversity of microorganisms in global fermented foods and beverages. Front. Microbiol. 7:377. doi: 10.3389/fmicb.2016.00377

Tedesco, I., Carbone, V., Spagnuolo, C., Minasi, P., and Russo, G. L. (2015). Identification and quantification of flavonoids from two southern italian cultivars of Allium cepa L., Tropea (Red Onion) and Montoro (Copper Onion), and their capacity to protect human erythrocytes from oxidative stress. J. Agric. Food Chem. 63, 5229-5238. doi: 10.1021/acs.jafc.5b01206

van Poppel, G., Verhoeven, D. T. H., Verhagen, H., and Goldbohm, R. A. (1999). Brassica vegetables and cancer prevention. Epidemiol. Mech. Adv. Exp. Med. Biol. 472, 159-168. doi: 10.1007/978-1-4757-3230-6_14

Wang, H. C., Pao, J., Lin, S. Y., and Sheen, L. Y. (2012). Molecular mechanisms of garlic-derived allyl sulfides in the inhibition of skin cancer progression. Ann. N.Y. Acad. Sci. 1271, 44-52. doi: 10.1111/j.1749-6632.2012.06743.x

Wang, T., Li, C., Liu, Y., Li, T., Zhang, J., and Sun, Y. (2015). Inhibition effects of Chinese cabbage powder on aflatoxin B1-induced liver cancer. Food Chem. 186, 13-19. doi: 10.1016/j.foodchem.2015.02.138

Warriner, K., and Namvar, A. (2010). The tricks learnt by human enteric pathogens from phytopathogens to persist within the plant environment. Curr. Opin. Biotechnol. 21, 131-136. doi: 10.1016/j.copbio.2010.01.004

Watanabe, M., Musumi, K., and Ayugase, J. (2011). Carotenoid pigment composition, polyphenol content, and antioxidant activities of extracts from orange-colored Chinese cabbage. LWT Food Sci. Technol. 44, 1971-1975. doi: 10.1016/j.lwt.2011.04.010
Wei, B., Cha, S. Y., Kang, M., Kim, Y. J., Cho, C. W., Rhee, Y. K., et al. (2015). Antiviral activity of Chongkukjang extracts against influenza A virus in vitro and in vivo. J. Ethnic Foods 2, 47-51. doi: 10.1016/j.jef.2015.04.001

Wills, R. B. H., and Rangga, A. (1996). Determination of carotenoids in Chinese vegetables. Food Chem. 56, 451-455. doi: 10.1016/0308-8146(95)00226-X

Wu, A. H., Yang, D., and Pike, M. C. (2000). A meta-analysis of soyfoods and risk of stomach cancer: the problem of potential confounder. Cancer Epidemiol. Biomarkers. Prev. 9, 1051-1058.

Yang, D., Liu, X., Liu, M., Chi, H., Liu, J., and Han, H. (2015). Protective effects of quercetin and taraxasterol against $\mathrm{H}_{2} \mathrm{O}_{2}$-induced human umbilical vein endothelial cell injury in vitro. Exp. Ther. Med. 10, 1253-1260. doi: 10.3892/etm.2015.2713

Yang, G., Wang, S., Zhong, L., Dong, X., Zhang, W., Jiang, L., et al. (2012). 6-gingerol induces apoptosis through lysosomal-mitochondrial axis in human hepatoma G2 cells. Phytother. Res. 26, 1667-1673. doi: 10.1002/pt r. 4632

Yang, H. J., Jang, D. J., Chung, K. R., Kim, K. S., and Kwon, D. Y. (2015). Origin names of gochu, kimchi, and bibimbap. J. Ethnic Foods 2, 162-172. doi: 10.1016/j.jef.2015.11.006

Yang, J. L., Lee, S. H., and Song, Y. S. (2003). Improving effect of powders of cooked soybean and chongkukjang on blood pressure and lipid metabolism in spontaneously hypertensive rats. Korean J. Food Nutr. 32, 899-906. doi: 10.3746/jkfn.2003.32.6.899

Yoo, S. K., Kang, S. M., and Noh, Y. S. (2000). Quality properties on soy bean pastes made with microorganisms isolated from traditional soybean pastes. Korean J. Food. Sci. Technol. 32, 1266-1270.

Yoon, J. Y., Jung, K. O., Kim, S. H., and Park, K. Y. (2004). Antiobesity effect of baek-kimchi (whitish baechu kimchi) in rats fed high fat diet. J. Food Sci. Nutr. 9, 259-264. doi: 10.3746/jfn.2004.9.3.259

Conflict of Interest Statement: The authors declare that the research was conducted in the absence of any commercial or financial relationships that could be construed as a potential conflict of interest.

Copyright (c) 2016 Patra, Das, Paramithiotis and Shin. This is an open-access article distributed under the terms of the Creative Commons Attribution License (CC BY). The use, distribution or reproduction in other forums is permitted, provided the original author(s) or licensor are credited and that the original publication in this journal is cited, in accordance with accepted academic practice. No use, distribution or reproduction is permitted which does not comply with these terms. 